\title{
Benthic diatoms and macroinvertebrates status with relevant to sediment quality of islands shores in the Nile River, Egypt
}

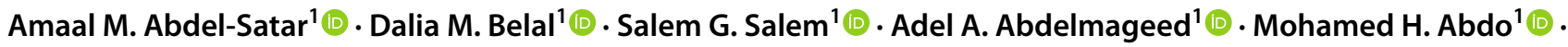 \\ Soad S. Abdel Gawad ${ }^{1}$ (1) - Afify D. G. Al-Afify ${ }^{1}$ (D)
}

Received: 6 November 2021 / Accepted: 15 January 2022 / Published online: 14 February 2022

(c) The Author(s) 2022

\begin{abstract}
Sediments are utilized as a marker for events that endure long enough to manifest their environmental impacts and determine the contamination levels. The purpose of the present study was to highlight the current sediment quality of four Nile islands shores by utilizing a variety of physical, chemical, and biological aspects and indices. In addition, the status of benthic diatoms and macroinvertebrates, as well as their responses to sediment variables were investigated. The metals followed a decreasing concentration order: $\mathrm{Al}>\mathrm{Fe}>\mathrm{Mn}>\mathrm{Zn}>\mathrm{Ni} \approx \mathrm{Cr}>\mathrm{Cu}>\mathrm{Co}>\mathrm{Pb}>\mathrm{Cd}$. The outcomes of metal pollution indices revealed some localized contaminated sites, by mostly $\mathrm{Ni}$ and $\mathrm{Cd}$. In addition, a moderate toxic risk from metals was observed for El-Keratten shores, while the sediments of El-Warraq, El-Zamalek, and El-Manial islands shores were at low toxic risk. A total of 112 diatom species belonging to 24 genera were identified in the total sample set, where most of the diatoms encountered were cosmopolitan. Metals had a remarkable impact on the composition, distribution, and dominance of diatom assemblages, but had little effect on diatom diversity, while there was a noticeable effect of grain size on diatom distribution and diversity. Thirty-four species of benthic invertebrates were identified in the collected samples from the islands shores. The dominant taxa and groups of benthic invertebrates at different islands were affected by various sediment parameters, where the levels and types of such variables differed from one species to another.
\end{abstract}

Amaal M. Abdel-Satar

abdelsatarmena11@yahoo.com

1 National Institute of Oceanography and Fisheries, NIOF,

Cairo, Egypt 


\section{Graphical abstract}

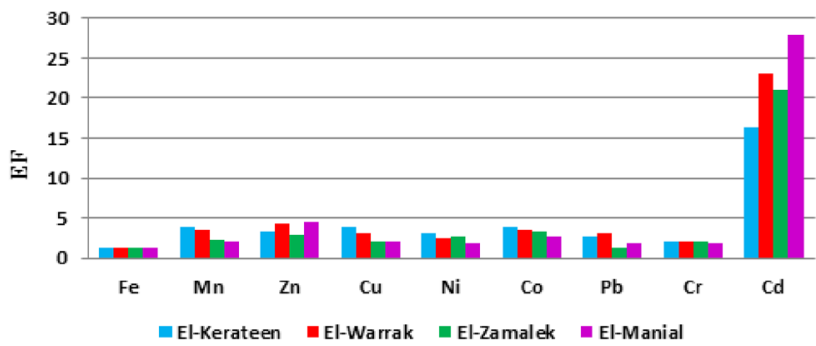

EF values for metals in Nile islands sediment

Diatom diversity index
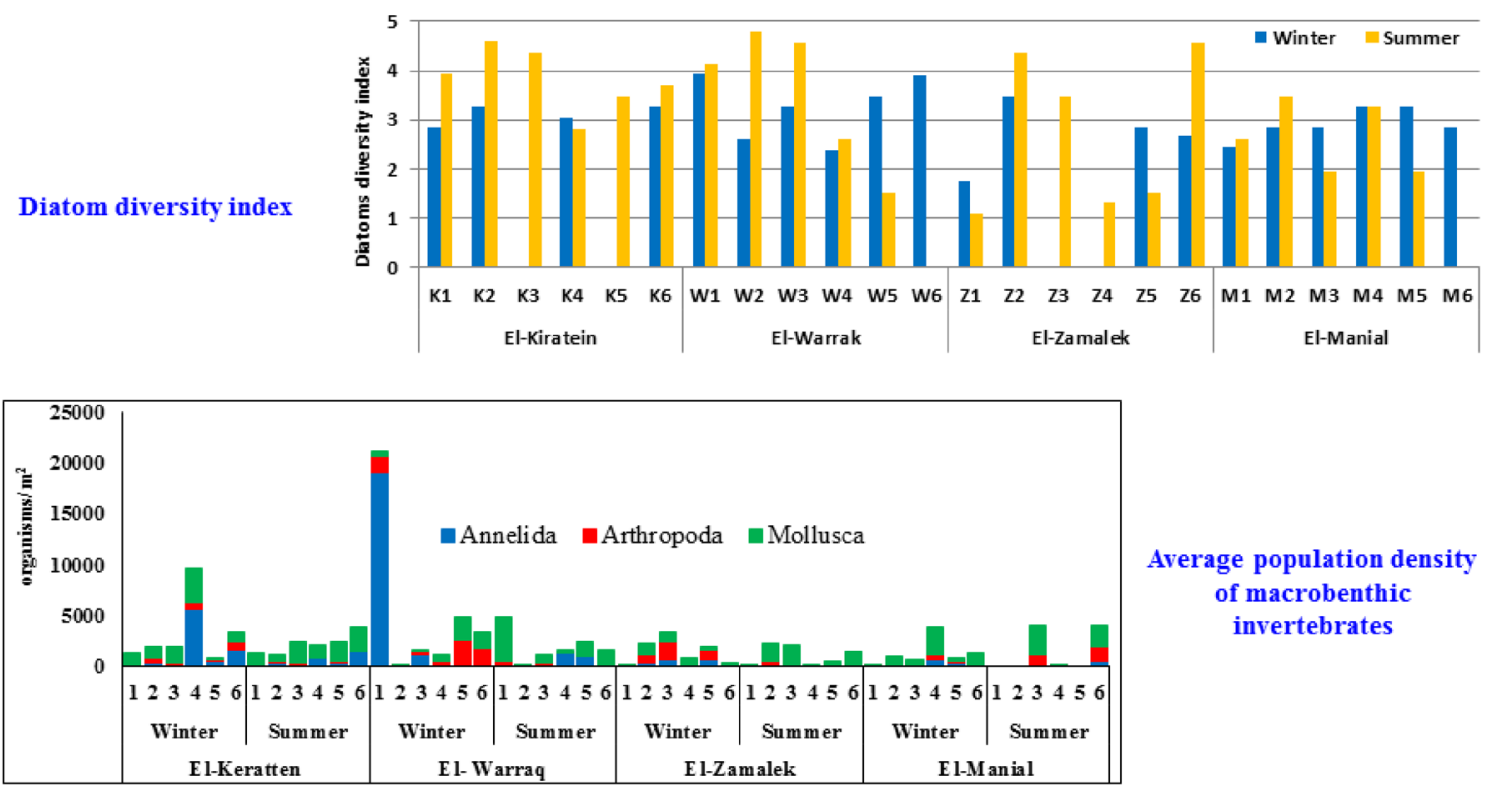

Average population density of macrobenthic invertebrates

Keywords Sediment quality $\cdot$ Heavy metals $\cdot$ Sediment assessment $\cdot$ Attached diatoms $\cdot$ Macrobenthic invertebrates $\cdot$ Nile River islands

\section{Introduction}

Freshwater is necessary for human survival, and its purity is a global problem. The Nile River is Egypt's lifeblood and the primary supply of freshwater for nearly all drinking and irrigation needs in Egypt (Abdel-Satar et al. 2017a). In Egypt, there are no systematic monitoring systems for recognizing and determining different types of contaminants in the Nile River ecosystem, where numerous types of organic and inorganic pollutant loading are prevalent (AlAfify and Abdel-Satar 2020; Othman et al. 2021; Shalaby et al. 2018). The Nile River water quality are influenced not only by water management interventions such as the hydrodynamic regimes regulated by the Nile barrages, but also, by the land and water use, including agricultural return, industrial, municipal and river ships wastewaters. Because of the increase of industrial, agricultural, and recreational activities and a poorly constructed drainage and sewerage infrastructure, the quality of Nile water is a severe concern
(Abdel-Satar et al. 2017a). As a result of upstream dam projects on the Nile River, water use by neighboring nations, and population increase, Egypt's Nile River is seriously environmental changed (Hussein et al. 2021).

From Aswan to the Mediterranean Sea, the Nile River features hundreds of islands. The deposition of coarse material from the suspended load resulted in the formation of the fluvial island. The island arose as a result of the river's inability to transfer the bed load, so it gathered to create the early stage of the island, after which it received fresh deposits, causing it to grow in length and width. Aswan High Dam (AHD) construction has resulted in significant changes in hydrological properties downstream of the dam, impacting river morphology, including islands type and formation. The number and size of the islands have shrunk as a result of the operation of the AHD, which has lowered the rate of suspended sediment transfer by limiting the flow rate downstream of the dam. Where the merging of islands with the east or west bank occurred and resulted in a reduction in the number of islands. 


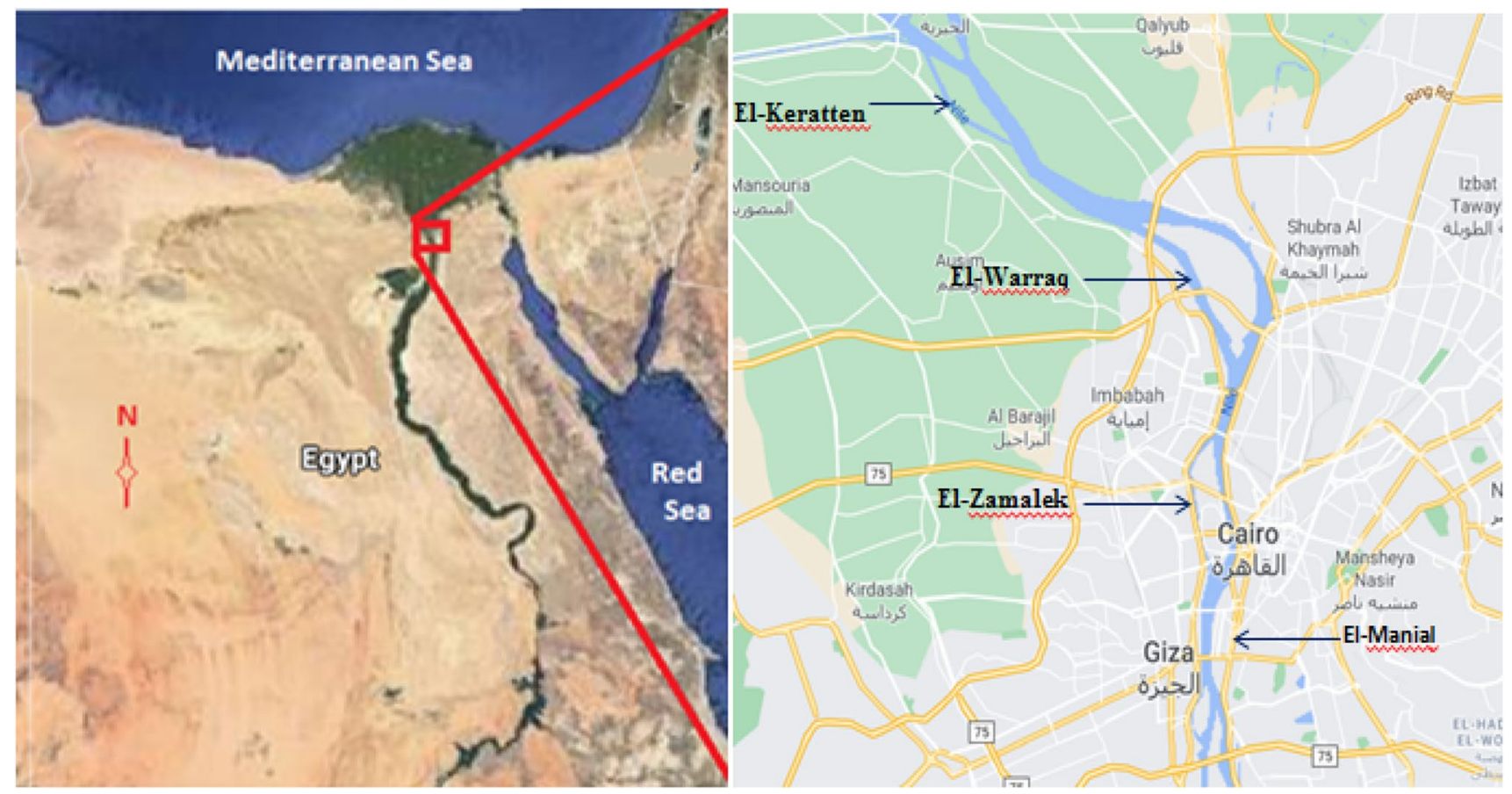

Fig. 1 Egypt Map showing the four selected islands

In certain circumstances, islands have been merged to form a single island (Raslan and Salama 2015).

Permanent islands remain unchanged without being attached to the banks, have permanent vegetation, and have distinct sand bars, while the islands that appear during low water levels and then become submerged during high water levels are seasonal (Sadek 2013). The majority of the permanent Nile River islands have seen rapid changes in land usage in recent years (Taha 2014). The urbanization trend continues, resulting in significant increases in metropolitan areas and a decrease in green space, where the built-up area has expanded due to agricultural land use. As a result, the morphology of the Nile River around the islands has changed (Raslan and Salama 2015). River islands have economic value, since they have a lot of potential for development. The Nile River islands in Great Cairo are regarded as a true breathing space (Farag et al., 2013). They've become one of Egypt's most important waterbird wintering grounds. Migratory birds use these islands as a layover. In addition, the islands are used for seasonal agriculture, fish farming, and wildlife refuges (Sadek 2013).

Sediment is essential in river limnological and environmental studies, because they have a long residence time for interaction with biotic components in the ecosystem and also act as a buffer for dissolved metals control (Abdel-Satar 2005). Sediment serves as a sponge for pollutants in rivers, such as heavy metals, but it also serves as a secondary source of pollutants in river water, and is thus used as a measure of aquatic environment quality (Abou El-Anwar et al. 2021). Heavy metal contamination of aquatic systems has attracted public attention in recent decades due to its toxicity, persistence, and non-degradability in the environment (Al-Afify and Abdel-Satar 2020; Yacoub et al. 2021). Metals accumulate in the sediment due to a variety of external environmental variables including $\mathrm{pH}$, ionic strength, redox potential, the concentration and type of inorganic and organic chelators, and the accessible surface area for adsorption caused by grain size distribution variation (Nazeer et al. 2016). Metals in sediment can be transmitted directly into aquatic ecosystems and can be easily adsorbed by plant roots and organisms and, therefore, enter the food chain, posing major environmental and health problems (Tang et al. 2020).

Diatoms are used to monitor the ecological state of aquatic systems, they respond rapidly to any shift of environmental condition (Pandey et al. 2017). The relationship between diatoms and heavy metal concentration has gained more attention in recent years, where diatoms respond to high metal concentrations in different ways. Shifting in dominant taxa towards more tolerant species is recorded; also the same species show different frustule and cell morphology when subjected to the high concentration of metal and leading to cell deformations (Lavoie et al. 2017). Diatoms also help metals such as $\mathrm{Pb}, \mathrm{Zn}$, and Fe bioaccumulate, making them valuable contributors to global nutrient recycling (Long et al. 2019).

Benthic macroinvertebrate assemblages have been utilized to assess the ecological implications of heavy metal 
Table 1 GPS coordinates for the River Nile islands, and the characteristics of Nile island water

\begin{tabular}{|c|c|c|c|c|c|c|c|c|c|}
\hline Island & Site code & Latitude (E) & Longitude (N) & $\begin{array}{l}\text { Surface } \\
\text { area }\left(\mathrm{Km}^{2}\right)\end{array}$ & Water depth $(\mathrm{m})$ & $\begin{array}{l}\text { Trans } \\
\mathrm{Cm}\end{array}$ & $\begin{array}{l}\mathrm{EC} \\
\mu \mathrm{S} \mathrm{cm}\end{array}$ & $\mathrm{pH}$ & $\begin{array}{l}\mathrm{DO} \\
\mathrm{mg} / \mathrm{l}\end{array}$ \\
\hline \multirow[t]{6}{*}{ El-Kerateen } & $\mathrm{K} 1$ & $30^{\circ} 09^{\prime} 05.3^{\prime \prime}$ & $31^{\circ} 09^{\prime} 23.0^{\prime \prime}$ & \multirow[t]{6}{*}{2.6} & \multirow[t]{6}{*}{$<1-10.2$} & \multirow[t]{6}{*}{$80-110$} & \multirow[t]{6}{*}{$370-418$} & \multirow[t]{6}{*}{$7.6-8.6$} & \multirow[t]{6}{*}{$6.1-10.0$} \\
\hline & $\mathrm{K} 2$ & $30^{\circ} 09^{\prime} 34.2^{\prime \prime}$ & $31^{\circ} 09^{\prime} 04.1^{\prime \prime}$ & & & & & & \\
\hline & K3 & $30^{\circ} 10^{\prime} 04.7^{\prime \prime}$ & $31^{\circ} 08^{\prime} 37.1^{\prime \prime}$ & & & & & & \\
\hline & $\mathrm{K} 4$ & $30^{\circ} 09^{\prime} 21.0^{\prime \prime}$ & $31^{\circ} 08^{\prime} 40.0^{\prime \prime}$ & & & & & & \\
\hline & K5 & $30^{\circ} 09^{\prime} 54.6^{\prime \prime}$ & $31^{\circ} 07^{\prime} 57.0^{\prime \prime}$ & & & & & & \\
\hline & K6 & $30^{\circ} 10^{\prime} 33.0^{\prime \prime}$ & $31^{\circ} 07^{\prime} 36.3^{\prime \prime}$ & & & & & & \\
\hline \multirow[t]{6}{*}{ El-Warrak } & $\mathrm{W} 1$ & $30^{\circ} 05^{\prime} 33.5^{\prime \prime}$ & $31^{\circ} 13^{\prime} 53.1^{\prime \prime}$ & \multirow[t]{6}{*}{7.3} & \multirow[t]{6}{*}{$<1-17.2$} & \multirow[t]{6}{*}{$90-120$} & \multirow[t]{6}{*}{$370-416$} & \multirow[t]{6}{*}{$8.3-8.6$} & \multirow[t]{6}{*}{$7.2-10.1$} \\
\hline & W2 & $30^{\circ} 06^{\prime} 35.4^{\prime \prime}$ & $31^{\circ} 14^{\prime} 22.4^{\prime \prime}$ & & & & & & \\
\hline & W3 & $30^{\circ} 07^{\prime} 48.5^{\prime \prime}$ & $31^{\circ} 13^{\prime} 05.7^{\prime \prime}$ & & & & & & \\
\hline & W4 & $30^{\circ} 06^{\prime} 24.6^{\prime \prime}$ & $31^{\circ} 13^{\prime} 15.8^{\prime \prime}$ & & & & & & \\
\hline & W5 & $30^{\circ} 07^{\prime} 13.0^{\prime \prime}$ & $31^{\circ} 12^{\prime} 49.5^{\prime \prime}$ & & & & & & \\
\hline & W6 & $30^{\circ} 07^{\prime} 55.2^{\prime \prime}$ & $31^{\circ} 11^{\prime} 48.6^{\prime \prime}$ & & & & & & \\
\hline \multirow[t]{6}{*}{ El-Zamalek } & $\mathrm{Z} 1$ & $30^{\circ} 02^{\prime} 14.5^{\prime \prime}$ & $31^{\circ} 13^{\prime} 25.2^{\prime \prime}$ & \multirow[t]{6}{*}{3.6} & \multirow[t]{6}{*}{$<1-13.6$} & \multirow[t]{6}{*}{$85-100$} & \multirow[t]{6}{*}{$368-423$} & \multirow[t]{6}{*}{$7.6-8.5$} & \multirow[t]{6}{*}{ 7.1-10.6 } \\
\hline & $\mathrm{Z} 2$ & $30^{\circ} 02^{\prime} 59.5^{\prime \prime}$ & $31^{\circ} 13^{\prime} 42.9^{\prime \prime}$ & & & & & & \\
\hline & $\mathrm{Z3}$ & $30^{\circ} 03^{\prime} 37.2^{\prime \prime}$ & $31^{\circ} 13^{\prime} 32.0^{\prime \prime}$ & & & & & & \\
\hline & $\mathrm{Z} 4$ & $30^{\circ} 03^{\prime} 00.9^{\prime \prime}$ & $31^{\circ} 13^{\prime} 05.4^{\prime \prime}$ & & & & & & \\
\hline & $\mathrm{Z} 5$ & $30^{\circ} 03^{\prime} 48.8^{\prime \prime}$ & $31^{\circ} 12^{\prime} 54.6^{\prime \prime}$ & & & & & & \\
\hline & Z6 & $30^{\circ} 04^{\prime} 25.5^{\prime \prime}$ & $31^{\circ} 13^{\prime} 22.5^{\prime \prime}$ & & & & & & \\
\hline \multirow[t]{6}{*}{ El-Manial } & M1 & $30^{\circ} 00^{\prime} 23.1^{\prime \prime}$ & $31^{\circ} 13^{\prime} 29.7^{\prime \prime}$ & \multirow[t]{6}{*}{2.1} & \multirow[t]{6}{*}{$1-12.6$} & \multirow[t]{6}{*}{ 80-105 } & \multirow[t]{6}{*}{$313-434$} & \multirow[t]{6}{*}{$7.8-8.6$} & \multirow[t]{6}{*}{$6.6-11.6$} \\
\hline & M2 & $30^{\circ} 00^{\prime} 55.1^{\prime \prime}$ & $31^{\circ} 14^{\prime} 40.8^{\prime \prime}$ & & & & & & \\
\hline & M3 & $30^{\circ} 01^{\prime} 43.9^{\prime \prime}$ & $31^{\circ} 13^{\prime} 49.9^{\prime \prime}$ & & & & & & \\
\hline & M4 & $30^{\circ} 00^{\prime} 59.7^{\prime \prime}$ & $31^{\circ} 13^{\prime} 16.3^{\prime \prime}$ & & & & & & \\
\hline & M5 & $30^{\circ} 01^{\prime} 43.8^{\prime \prime}$ & $31^{\circ} 13^{\prime} 21.3^{\prime \prime}$ & & & & & & \\
\hline & M6 & $30^{\circ} 02^{\prime} 09.7^{\prime \prime}$ & $31^{\circ} 13^{\prime} 40.4^{\prime \prime}$ & & & & & & \\
\hline
\end{tabular}

Trans.: transparency, EC: electrical conductivity, DO: dissolved oxygen

contamination in the aquatic system, because they contain species with varying sensitivity to pollutants. Metal contamination can diminish the number of species of benthic macroinvertebrates also, their growth, density, and production may be affected (Qu et al. 2010).

There are no studies about the Nile islands shores environment and biodiversity to improve their local environment, where the present study is considered the first one. The study aimed to: (a) use a variety of physical, chemical, and biological indices to assess the current sediment quality of four Nile island shores; (b) investigate the status of benthic diatoms and macroinvertebrates relevant to the sediment quality of island shores in the Nile River, Egypt.

\section{Materials and methods}

\subsection{Sampling area}

The Nile islands in Great Cairo are characterized by high fertility and suitability for agricultural activities (Taha 2014). The current research focuses on four permanent islands in Great Cairo (Fig. 1): El-Manial and El-Zamalek, which are largely residential regions, as well as El-Warraq and El-Keratten, which are mostly agricultural land with limited residential areas. Table 1 lists the descriptions of Nile island sites as well as the features of Nile island water.

\subsection{Samples collection and analysis}

The samples were collected twice, in summer and winter seasons from the selected islands in 2020. Six sites were chosen in each island for samples collection. Eckman Dredge sampling equipment was used to gather sediment samples from the top $15 \mathrm{~cm}$ of the bottom layer. For metal analysis, the sediment samples were taken to the lab and air-dried. The dried sample was then passed through a 2-mm sieve to remove any stones or plant pieces, where $0.5 \mathrm{~g}$ of sediment samples were digested according to Kouadia and Trefry (1987) method. Cd, Pb, Cr, Co, Ni, Cu, Zn, Mn, Fe and $\mathrm{Al}$ were estimated in the digestive sediment samples using Inductively Coupled Plasma Mass Spectrometry (iCAP TQ ICP-MS) Thermo Scientific-Germany. Triplicate readings were used to ensure precision in metal analysis, and 


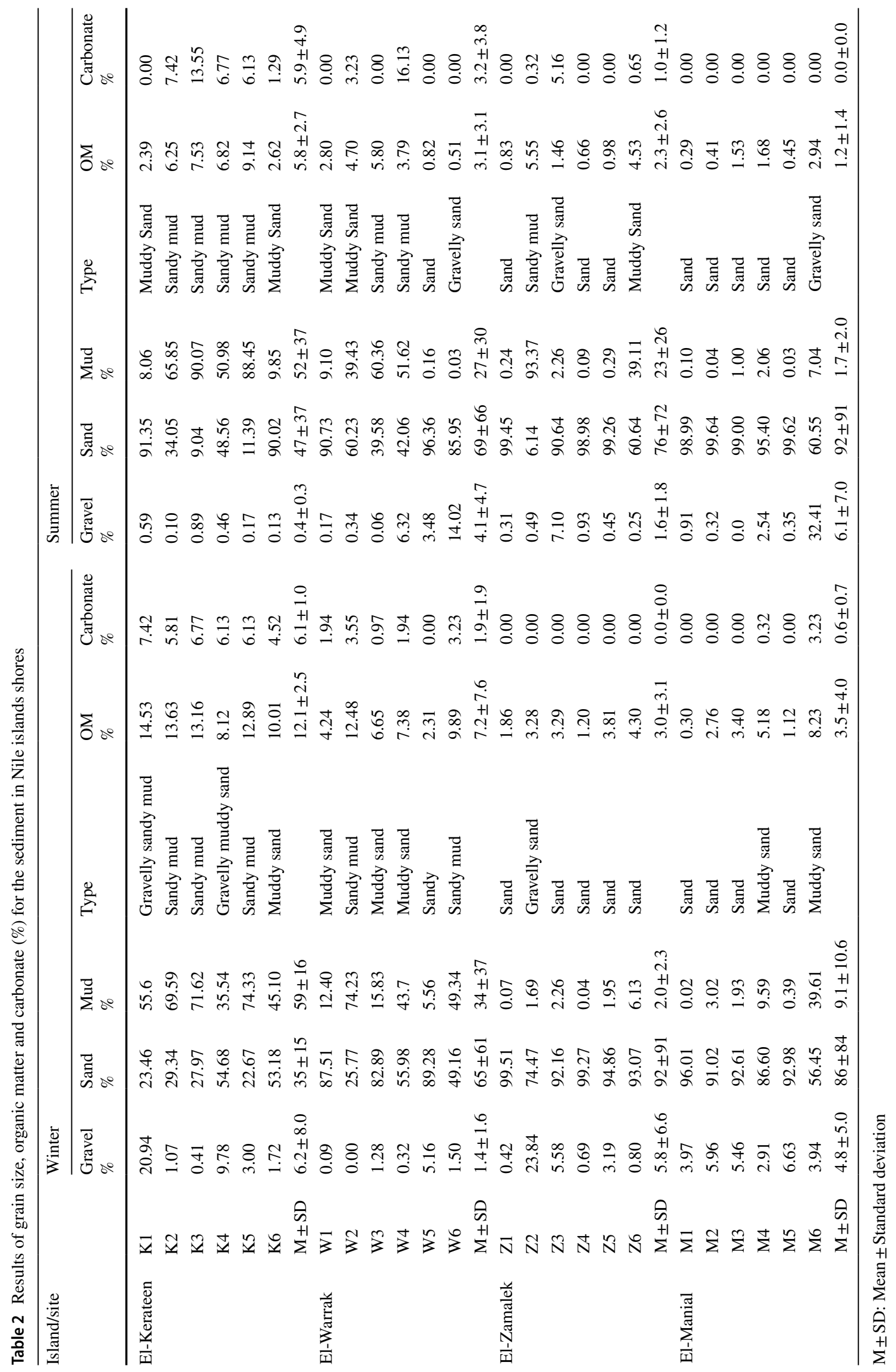


the mean value was calculated with relative standard deviations of less than 5\%. The dry sieving technique (Folk 1974) was used to assess grain size; the wet oxidation method was used to determine sediment organic matter (OM) (Loring and Rantala 1992) and carbonate percent was measured as reported in American Society of Agronomy (1982).

To evaluate the metal ecological risk in islands sediment; single and integrated indices were used including pollution load index (PLI) (Tomlinson et al. 1980); enrichment factor (EF) (Yahaya et al. 2012); geoaccumulation index (I-geo) (Muller 1969); modified contamination degree (mCd) (Abrahim and Parker 2008); potential ecological risk index (ER) (Hakanson 1980, 1988); toxic risk index (TRI) (Gao et al. 2018; Zhang et al. 2016) and finally the toxic unit (TU) (Pedersen et al. 1998). The supplementary information (Text S1) provides more information about these indices.

Diatom microscope slides were prepared according to ANS (2002), in which $2 \mathrm{~g}$ of air-dried sediment sample was digested using $98 \%$ sulphuric acid and $65 \%$ nitric acid in the ratio of $1: 2$, till complete decomposition of organic matter. The samples were then washed many times until $\mathrm{pH}$ to be $>6.5$. The diatom samples were pipetted onto cleaned coverslips, where microscope slides were prepared with Naphrax and viewed under Zeiss light microscope at a 40X magnification.

Three replicate samples for macrobenthic invertebrate community assessment were collected from the shores of the Nile islands using Ekman Grab bottom sampler. The samples were washed to remove any adhering sediments or mud through a sieve screen of $500 \mu \mathrm{m}$ mesh diameter. The samples were fixed with a $10 \%$ neutral formalin solution. In the laboratory, the samples were washed again in a net of $500 \mu \mathrm{m}$ mesh diameter. The samples were classified using a binuclear dissecting microscope. Population density (PD) was calculated and expressed as organisms $/ \mathrm{m}^{2}$. Macrobenthic invertebrate fauna were identified using Brinkhurst (1966), Brinkhurst and Jamison (1971), Brown et al. (1984), Pennak (1953), and Wirth and Stone (1963).

\subsection{Statistical analysis}

The data for sediment were tested for spatial and temporal significant differences using one-way ANOVA. In addition, the Pearson correlation index was used to calculate the correlations between different variables in the sediment of Nile islands shores. Canonical correspondence analysis (CCA) was used to evaluate the relationship between the abundance of diatoms and macrobenthos sequences with sediment variables in Nile shores using Canoco for Windows version 4.5 (ter Braak 1987). The diversity index and evenness for diatom at all sampled sites were calculated using primer software version 5 (Clarke and Gorley 2001). The nonparametric multiplicative regression (NPMR) was applied to predict the relationships between different indices through the Microsoft Excel program.

\section{Results and discussion}

\subsection{Sediment analysis}

The bottom sediments of rivers have a significant impact on aquatic life and water quality (Abou El-Anwar et al. 2021). The grain size of sediments is an essential factor influencing the metal mobility and dispersion in a river system (AbdelSatar 2005). Table 2 summarizes the grain size distributions for sediment samples collected from four Nile islands shores. Grain size analysis has shown that El-Keratten sediments were mainly composed of mud, reflect the agricultural activity on the island, while El-Manial, El-Zamalek, and El-Warraq islands sediment possessed sand with an average percent 89,84 , and $67 \%$, respectively.

The average OM values for the sediment of El-Manial, El-Zamalek, El-Warraq, and El-Keratten islands were $2.4,2.6,4.1$, and $8.9 \%$, respectively, Table 2. OM showed a significant correlation with mud percent in all islands sediment, Table S3, where the particle composition of the Nile islands sediment and the organic load entering the Nile with various wastes control the organic content distribution in the Nile sediments (Abdel-Satar 2005). Because of the formation of complexes between the metals and OM, the availability of metals to organisms will be reduced (Abdel-Satar et al. 2017b). OM showed significant correlations $(n=12, p<0.05)$ with metals $(\mathrm{Mn}, \mathrm{Zn}$, $\mathrm{Cu}, \mathrm{Pb}$, and $\mathrm{Cd}$ ) for different islands sediments samples (Table S3), reflecting the role of OM in the bioavailability and mobility of metals (Qu et al. 2019). The stability of natural humic complexes generally follows the IrvingWilliams order for divalent trace elements complexation: $\mathrm{Hg}>\mathrm{Cu}>\mathrm{Pb}>\mathrm{Zn}>\mathrm{Cd}>\mathrm{Fe}$ in Nile sediments (AbdelSatar 2005).

Carbonate content was completely depleted in most sediment samples for El-Manial and El-Zamalek islands, while the increase of carbonate percent in El-Warraq and El-Keratten samples may be related to the mud content, Table 2. The significant correlations were observed between mud and carbonate contents (Table S3), where the fermentation processes, which may occur in sinking dead organisms, generating $\mathrm{OM}$ and releasing calcium carbonate to surface sediment (Abdel-Satar 2005).

\subsection{Metals abundances}

Because sediments show less fluctuation over time than dissolved metals in overlying water columns, they are favored as a monitoring method (Badawy et al. 2021). pH 
Table 3 Basic statistics of heavy metals $\left(\mu \mathrm{g} \mathrm{g}^{-1}\right)$ in the sediment of Nile islands shores

\begin{tabular}{|c|c|c|c|c|c|c|c|c|c|}
\hline \multirow[t]{2}{*}{ Metal } & \multirow[t]{2}{*}{ Season } & & \multirow[t]{2}{*}{ El-Kerateen } & \multirow[t]{2}{*}{ El-Warrak } & \multirow[t]{2}{*}{ El-Zamalek } & \multirow[t]{2}{*}{ El-Manial } & \multirow[t]{2}{*}{$\begin{array}{l}\text { EPA } \\
(2006)\end{array}$} & \multicolumn{2}{|c|}{$\begin{array}{l}\text { MacDonald } \\
\text { (2000) }\end{array}$} \\
\hline & & & & & & & & PEL & TEL \\
\hline \multirow[t]{4}{*}{$\mathrm{Al}$} & \multirow[t]{2}{*}{$\mathrm{W}$} & Range & $11,897-35,765$ & $10,831-24,209$ & $17,561-29,251$ & $13,169-35,506$ & - & - & - \\
\hline & & Mean \pm SD & $20,859 \pm 8421$ & $16,067 \pm 5775$ & $22,958 \pm 4814$ & $22,642 \pm 9926$ & & & \\
\hline & \multirow[t]{2}{*}{ S } & Range & $23,158-78,427$ & $18,712-71,833$ & $17,388-60,614$ & $11,755-39,395$ & & & \\
\hline & & Mean \pm SD & $53,701 \pm 22,975$ & $48,675 \pm 21,444$ & $40,690 \pm 17,252$ & $22,818 \pm 9978$ & & & \\
\hline \multirow[t]{4}{*}{$\mathrm{Fe}$} & \multirow[t]{2}{*}{ W } & Range & $11,288-17,786$ & $12,907-16,764$ & $13,859-22,458$ & $13,071-20,970$ & 20,000 & - & - \\
\hline & & Mean \pm SD & $14,693 \pm 2391$ & $14,445 \pm 1689$ & $17,284 \pm 3647$ & $16,458 \pm 3111$ & & & \\
\hline & \multirow[t]{2}{*}{$S$} & Range & $13,849-48,562$ & $13,295-51,563$ & $13,797-37,472$ & $12,289-31,596$ & & & \\
\hline & & Mean \pm SD & $30,586 \pm 14,132$ & $32,612 \pm 16,359$ & $26,978 \pm 8798$ & $16,822 \pm 7288$ & & & \\
\hline \multirow[t]{4}{*}{ Mn } & \multirow[t]{2}{*}{ W } & Range & $592.1-2203$ & $406.8-1329$ & $335.4-825.5$ & $125.9-1237$ & 460 & - & - \\
\hline & & Mean \pm SD & $1084 \pm 620$ & $840 \pm 421$ & $591 \pm 161$ & $478 \pm 392$ & & & \\
\hline & \multirow[t]{2}{*}{$\mathrm{S}$} & Range & 774.5-1898 & $174.3-1679$ & 416.3-997.6 & $273.1-849.9$ & & & \\
\hline & & Mean \pm SD & $1194 \pm 416$ & $793 \pm 523$ & $702 \pm 204$ & $433 \pm 219$ & & & \\
\hline \multirow[t]{4}{*}{$\mathrm{Zn}$} & \multirow[t]{2}{*}{ W } & Range & $55.1-175.8$ & $57.3-197.8$ & $75.3-98.1$ & $45.6-193.8$ & 121 & 123 & 315 \\
\hline & & Mean \pm SD & $96.7 \pm 43.8$ & $121.3 \pm 60.1$ & $86.3 \pm 8.0$ & $124.8 \pm 62.9$ & & & \\
\hline & \multirow[t]{2}{*}{ S } & Range & $102.2-186.3$ & $79.9-147.1$ & $75.3-157.8$ & $45.0-185.5$ & & & \\
\hline & & Mean \pm SD & $141.0 \pm 32.1$ & $101.2 \pm 24.4$ & $97.6 \pm 30.8$ & $86.5 \pm 52.0$ & & & \\
\hline \multirow[t]{4}{*}{$\mathrm{Cu}$} & \multirow[t]{2}{*}{ W } & Range & $40.11-66.33$ & $22.23-53.98$ & $21.36-40.06$ & $10.73-44.82$ & 31.6 & 35.7 & 197 \\
\hline & & Mean \pm SD & $53.7 \pm 10.9$ & $39.4 \pm 12.7$ & $32.9 \pm 6.5$ & $25.3 \pm 12.7$ & & & \\
\hline & \multirow[t]{2}{*}{ S } & Range & $39.67-106.5$ & $19.12-54.75$ & $24.87-42.97$ & $15.37-35.25$ & & & \\
\hline & & Mean \pm SD & $64.4 \pm 25.4$ & $34.5-12.0$ & $32.7 \pm 8.0$ & $23.2 \pm 6.8$ & & & \\
\hline $\mathrm{Ni}$ & W & Range & $31.23-102.2$ & $32.72-59.84$ & $34.30-94.08$ & $12.56-64.43$ & 22.7 & 18 & 36 \\
\hline & & Mean \pm SD & $56.9 \pm 27.4$ & $40.1 \pm 11.2$ & $51.3 \pm 21.6$ & $32.8 \pm 17.6$ & & & \\
\hline & $S$ & Range & $74.11-182.2$ & $21.38-103.8$ & 47.94-99.11 & $21.29-62.30$ & & & \\
\hline & & Mean \pm SD & $101.9 \pm 40.1$ & $63.7 \pm 29.4$ & $74.2 \pm 21.4$ & $33.6 \pm 15.4$ & & & \\
\hline Co & W & Range & $11.04-33.83$ & $13.01-25.64$ & $12.85-21.04$ & $8.04-25.52$ & 50 & - & - \\
\hline & & Mean \pm SD & $21.2 \pm 9.6$ & $16.7 \pm 5.1$ & $18.4 \pm 2.9$ & $13.5 \pm 6.4$ & & & \\
\hline & $\mathrm{S}$ & Range & $30.06-41.54$ & $8.26-41.36$ & $20.47-31.53$ & $8.98-26.04$ & & & \\
\hline & & Mean \pm SD & $33.6 \pm 4.3$ & $25.9 \pm 12.1$ & $23.9 \pm 4.4$ & $13.6 \pm 6.5$ & & & \\
\hline $\mathrm{Pb}$ & W & Range & $9.26-27.26$ & $12.94-26.65$ & $5.86-12.12$ & $7.58-12.98$ & 35.8 & 35 & 91.3 \\
\hline & & Mean \pm SD & $18.8 \pm 6.1$ & $19.1 \pm 6.1$ & $10.0 \pm 2.3$ & $10.2 \pm 2.0$ & & & \\
\hline & S & Range & $5.58-29.12$ & $6.92-16.06$ & $6.22-11.14$ & $5.22-11.36$ & & & \\
\hline & & Mean \pm SD & $15.2 \pm 8.0$ & $10.1 \pm 3.40$ & $8.1 \pm 1.7$ & $8.2 \pm 2.4$ & & & \\
\hline $\mathrm{Cr}$ & W & Range & $19.01-126.8$ & $21.32-88.15$ & $24.25-96.86$ & $22.96-83.55$ & 43.4 & 37.3 & 90 \\
\hline & & Mean \pm SD & $49.6 \pm 43.0$ & $34.5 \pm 17.1$ & $57.6 \pm 29.2$ & $45.1 \pm 21.6$ & & & \\
\hline & $\mathrm{S}$ & Range & $71.93-147.7$ & $22.65-163.0$ & $36.03-133.5$ & $16.35-100.4$ & & & \\
\hline & & Mean \pm SD & $103.7 \pm 27.8$ & $93.8 \pm 50.7$ & $86.7 \pm 32.1$ & $48.3 \pm 34.4$ & & & \\
\hline $\mathrm{Cd}$ & W & Range & $1.02-2.18$ & $1.19-4.12$ & $1.47-4.44$ & $1.16-4.88$ & 0.99 & 0.596 & 3.53 \\
\hline & & Mean \pm SD & $1.6 \pm 0.4$ & $1.99 \pm 1.20$ & $2.39 \pm 1.09$ & $2.06 \pm 1.43$ & & & \\
\hline & $\mathrm{S}$ & Range & $1.12-2.02$ & $1.14-2.68$ & $1.26-3.12$ & $1.02-3.94$ & & & \\
\hline & & Mean \pm SD & $1.61 \pm 0.37$ & $1.62 \pm 0.55$ & $2.00 \pm 0.88$ & $1.87 \pm 1.09$ & & & \\
\hline
\end{tabular}

W: winter, S: summer, SD: standard deviation, TEL: threshold effect level, PEL: probable effect level

of Nile water was in the alkaline side (Table 2) that promotes the metal precipitation and possibly increases the metal levels in sediments (Abdel-Satar 2005). During the two study periods, the examined metals followed a decreasing average concentration order $\mathrm{Al}>\mathrm{Fe}>\mathrm{Mn}>\mathrm{Zn}>\mathrm{Ni} \approx$
$\mathrm{Cr}>\mathrm{Cu}>\mathrm{Co}>\mathrm{Pb}>\mathrm{Cd}$ in the Nile islands shores sediment, Table 3. The average concentrations maxima for all metals analyzed were in the El-Keratten Island sediment. All metals did not show any spatial variations during the studied periods for different islands. 
$\mathrm{Al}$ and Fe showed significant temporal variations for ElZamalek, El-Warraq and El-Keratten sediment samples. No criteria have been established for $\mathrm{Al}$, which is generally not harmful to biota. The average levels of $\mathrm{Al}$ and $\mathrm{Fe}$ were the lowest in El-Manial shores $\left(22,730\right.$ and $16,640 \mu \mathrm{g} \mathrm{g}^{-1}$, respectively), while the highest levels were recorded in ElKeratten and El-Warraq sediment, reflecting the agricultural wastes discharges containing high levels of metals. Fe concentrations in sediment of islands shores surpassed the freshwater guidelines (EPA 2006) on some samples especially in El-Keratten and El-Warraq and during summer season, Table 3.

Metals ( $\mathrm{Mn}, \mathrm{Zn}$, and $\mathrm{Cu}$ ) are essential micronutrients and have been demonstrated to be vital in plant and animal metabolism. Due to increased contamination of the world's surface waters and broad transmission of airborne contaminants, their concentrations may eventually approach lethal levels (Goldman 2009). The ranges of Mn, Zn, and
$\mathrm{Cu}$ concentrations in sediment Nile islands shores were 125.9-2202.6, 45.0-197.8, and 10.7-106.5 $\mu \mathrm{g} \mathrm{g}{ }^{-1}$, respectively. The studied sediment showed high levels of metals and their levels overstepped the freshwater sediment benchmarks (EPA 2006) on most samples, Table 3. The agricultural runoff, fertilizer leaching, and disposal of domestic sewage lead to an increase in the metals load to Nile River islands shores. These metals have limited solubility and are not biodegradable, but they commonly interact with inorganic and organic substances before settling to the bottom sediments of water bodies (Maina et al. 2019).

$\mathrm{Ni}$ is an essential element for microorganisms and plants, where it is a component of various enzymes that play critical roles in oxygen, nitrogen, and carbon cycling (Mulrooney and Hausinger 2003). In addition, Co acts as a catalyst in nitrogen fixation in different types of algae and is required for vitamin B-12 synthesis (Goldman 2009). The average Ni concentrations were 79.36, 53.25, 62.72,

Table 4 Pollution load index (PLI), modified contamination degree (mCd), potential ecological risk index, toxic unit (TU) and toxic risk index (TRI) for Nile islands shores sediment*

\begin{tabular}{lllllll}
\hline Island & Season & PLI & mCd & ER & TU & TRI \\
\hline El-Kerateen & Winter & $0.76-1.73(1.07)$ & $0.91-2.43(1.38)$ & $51.9-116.3(78.6)$ & $2.14-6.06(3.37)$ & $5.10-12.72(7.53)$ \\
& Summer & $1.12-1.82(1.48)$ & $1.41-2.74(1.92)$ & $65.7-122.5(93.6)$ & $4.08-8.22(5.38)$ & $8.22-15.69(11.03)$ \\
El-Warrak & Winter & $0.67-1.29(0.94)$ & $0.76-1.62(1.18)$ & $79.8-83.0(81.5)$ & $2.05-3.95(2.96)$ & $4.63-9.26(6.88)$ \\
& Summer & $0.51-1.91(1.13)$ & $0.60-2.36(1.38)$ & $45.8-129.0(76.1)$ & $1.66-6.37(3.88)$ & $3.93-13.49(8.21)$ \\
El-Zamalek & Winter & $0.76-1.07(0.92)$ & $0.93-1.57(1.21)$ & $79.1-80.7(79.9)$ & $2.42-4.62(3.29)$ & $5.76-10.81(7.73)$ \\
& Summer & $0.87-1.38(1.08)$ & $1.08-1.82(1.42)$ & $63.7-130.6(90.6)$ & $2.93-5.44(4.16)$ & $6.20-11.92(8.88)$ \\
El-Manial & Winter & $0.47-1.01(0.76)$ & $0.58-1.42(1.00)$ & $79.7-81.4(80.3)$ & $1.62-3.80(2.63)$ & $3.86-9.56(6.35)$ \\
& Summer & $0.53-1.11(0.71)$ & $0.64-1.38(0.92)$ & $43.7-134.2(73.4)$ & $1.79-3.89(2.48)$ & $4.10-8.29(5.90)$ \\
\hline
\end{tabular}

*minimum-maximum (mean)

ER

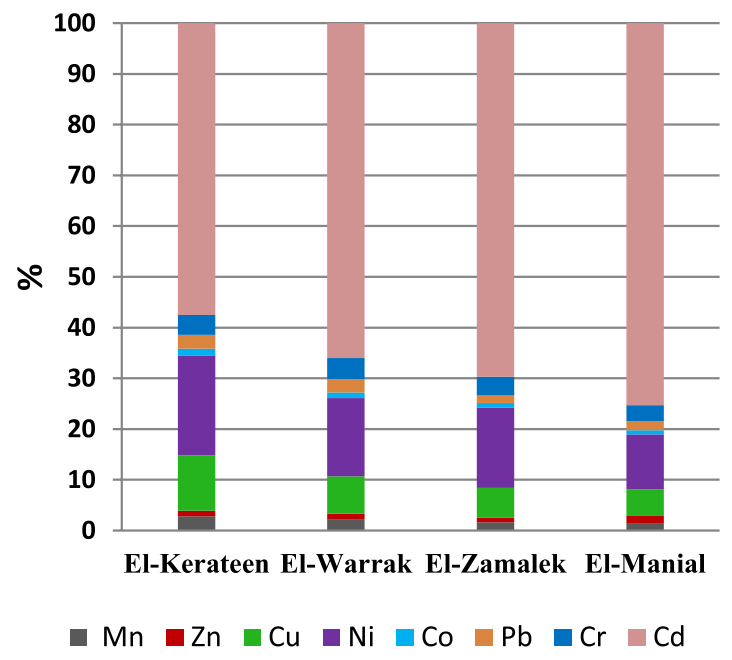

$\Sigma T U$

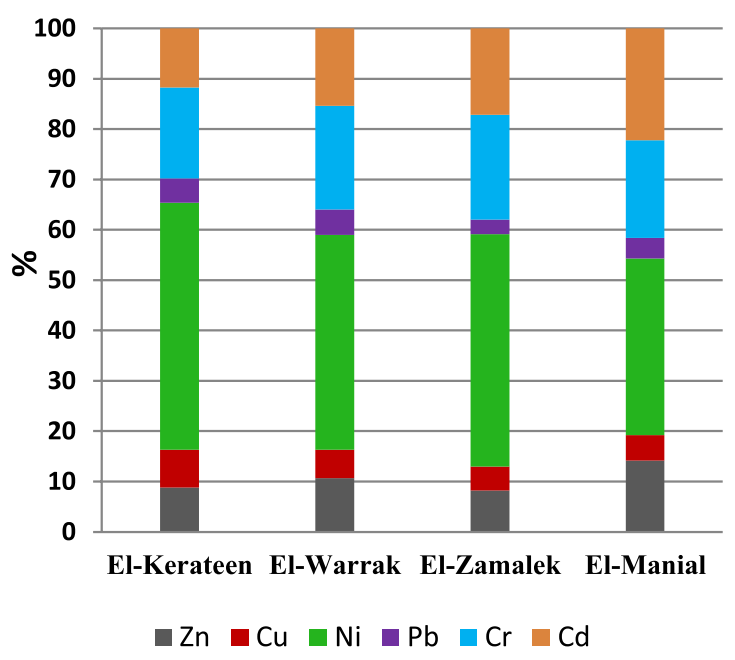

Fig. 2 Average contribution percentage of metals to ER and $\Sigma T U$ in Nile islands shores 
and $33.18 \mu \mathrm{g} \mathrm{g}^{-1}$ for El-Keratten, El-Warraq, El-Zamalek, and El-Manial shores, respectively, while the averages Co values were 27.42, 21.35, 21.12, and $13.57 \mu \mathrm{g} \mathrm{g}^{-1}$, respectively, El-Keratten showed the highest levels and El-Manial had the lowest. Ni concentrations in about $94 \%$ of samples overstepped the EPA (2006) guidelines at the two studied periods (Table 3), where domestic wastewater effluents are the most common cause of $\mathrm{Ni}$ contamination in aquatic habitats, as acidic beverages can dissolve $\mathrm{Ni}$ from pipes. Cr levels in Nile shores ranged from 16.35 to $163.1 \mu \mathrm{g} \mathrm{g}^{-1}$. The highest level was recorded at El-Warraq Island, while the minimum was observed at El-Manial. The average concentration of $\mathrm{Cr}$ showed the highest level in El-Keratten and the lowest in El-Manial. The concentrations of $\mathrm{Cr}$ are significantly higher than the amounts in the freshwater sediment guidelines (EPA 2006), such concentration is an indicator of high Nile islands activities, Table 3. $\mathrm{Cd}$ and $\mathrm{Pb}$ are hazardous metals with significant implications for the environment and human health. The presence of other metals, such as zinc, may aggravate cadmium toxicity (Rzętała et al. 2016). The levels of $\mathrm{Pb}$ were within the freshwater benchmark (EPA 2006) in all studied islands samples, while Cd overstepped the guidelines in all Nile shores samples, Table 3.

According to the correlation matrix based on Pearson's coefficient the mud \% and studied metals in El-Manial $(\mathrm{Cu}$, $\mathrm{Pb}, \mathrm{Cd}$ ), El-Zamalek ( $\mathrm{Fe}, \mathrm{Zn}, \mathrm{Cu}$ ), El-Warraq ( $\mathrm{Mn}, \mathrm{Cu}$, $\mathrm{Pb}, \mathrm{Cd})$, and El-Keratten $(\mathrm{Cu}, \mathrm{Pb}, \mathrm{Cd})$ showed significant correlations $(n=12, p<0.05)$, Table $\mathrm{S} 3$, implying that finer-grained sediments are linked to elevated heavy metal concentrations (Sayed and Abdel-Satar 2009). The results of correlation matrix $(n=12, p<0.05)$ for studied metals pairs in different islands shores illustrated common sources, Table S3.
Because of their toxicity, non-degradability, and biomagnification, which can pose a threat to ecosystems, heavy metals are an effective indicator of ecological environmental quality assessment (Abou El-Anwar et al. 2021). The ecologically adverse hazards of metals in Nile shores sediments were assessed using the threshold effects level (TEL) and probable effects level (PEL) according to MacDonald et al. (2000), Table 3. In the two studied periods, almost all islands sediment showed high levels of $\mathrm{Ni}$ and $\mathrm{Cd}$ exceeded the TEL. While, $\mathrm{Zn}, \mathrm{Cu}$, and $\mathrm{Cr}$ levels in Nile samples surpassed the TEL in El-Keratten shores in 42, $100 \& 67 \%$ of samples, respectively, while for El-Warraq shores in 25, 50 $\& 58 \%$ of samples, respectively. In addition, El-Zamalek and El-Manial shores in 8, 33 \& 92\% and 25, 8 \& 58\%, of samples showed high levels of $\mathrm{Zn}, \mathrm{Cu}$, and $\mathrm{Cr}$, respectively, reflecting rare adverse effects on aquatic biota inhabiting the Nile shores. In general, various metals sources to Nile shores include dry and wet fallout of air particle matter, decomposing of dead plants and animals, in addition to the discharge of various untreated wastes, including agricultural wastes, especially into El-Keratten shores.

\subsection{Sediment indices of Nile shores}

The sediment quality indices application can help to evaluate the detrimental effects of numerous anthropogenic contamination sources and is considered a suitable approach for monitoring water quality (Unda-Calvo et al. 2020). Average I-geo values for tested metals according to contamination classification (Müller 1969) indicated that El-Keratten sediment was virtually contaminated by $\mathrm{Mn}, \mathrm{Cu}, \mathrm{Ni}$, and $\mathrm{Cd}$, El-Warraq and El-Zamalek shores were contaminated by $\mathrm{Ni}$ and $\mathrm{Cd}$, and finally, El-Manial sediments had Cd contamination only (Fig. S1).

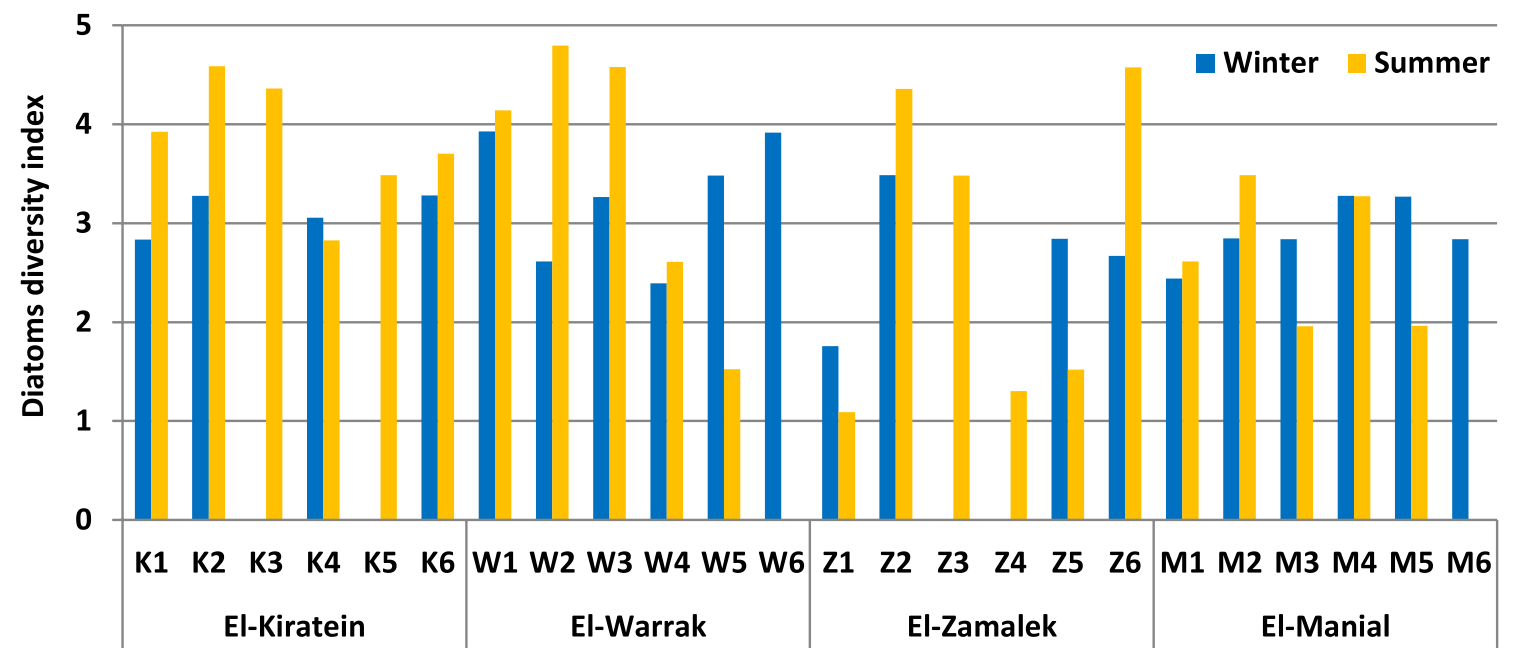

Fig. 3 Diatom diversity index at sites of four Nile islands during winter and summer. Note: Diatoms at sites K3, K5, Z3 and Z4 in winter and W6 in summer were not analyzed 


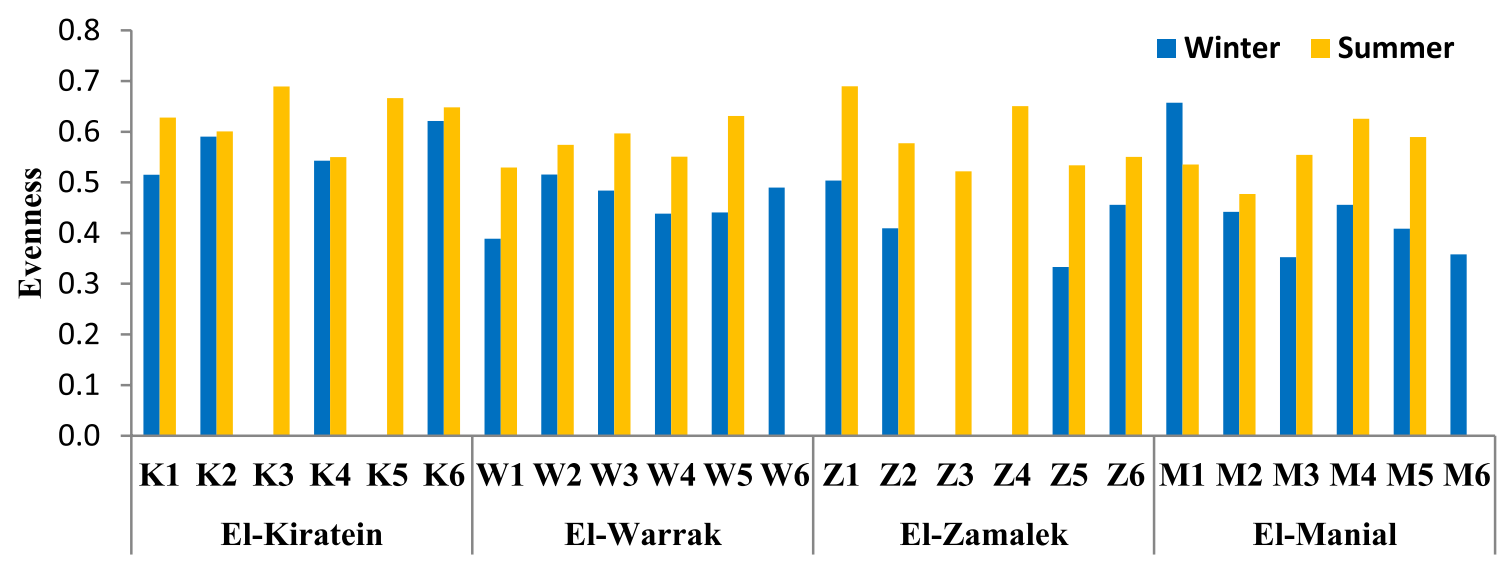

Fig. 4 Diatom evenness value at sites of four Nile islands during winter and summer
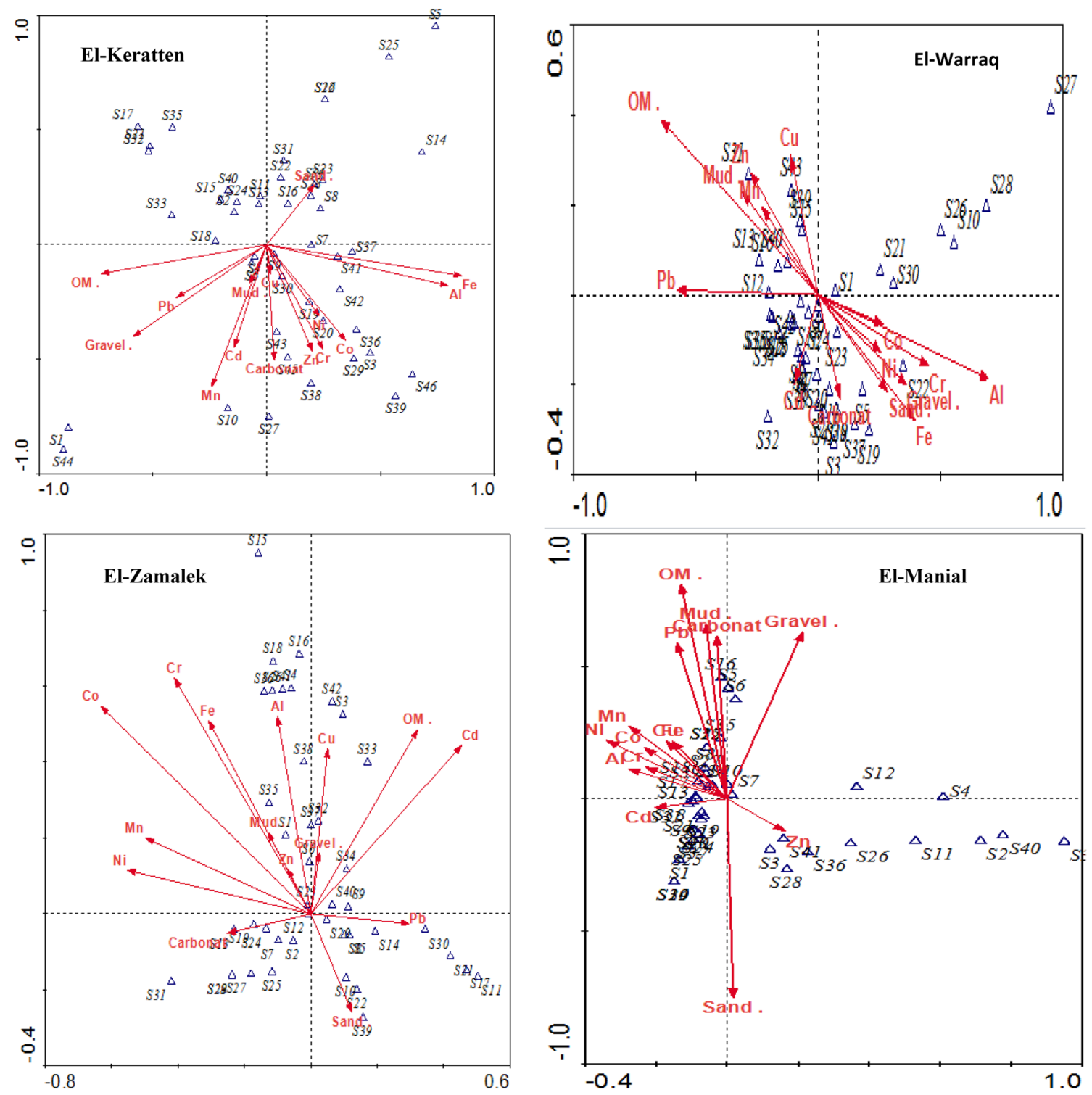

Fig. 5 Ordination diagram showing the result of CCA analysis for diatoms in the four studied islands 
Table 5 Coded diatom species included in the CCA and recorded with relative abundance $\geq 1 \%$ at the four islands shores

\begin{tabular}{|c|c|c|c|c|}
\hline \multicolumn{4}{|c|}{ Species code } & Species name \\
\hline & & & S1 & Achnanthes lanceolata Oestrup \\
\hline S1 & & & S2 & Achnanthes lanceolata var. rostrata $*$ Planothidium rostratum (Ostrup) Lange-Bertalot \\
\hline \multirow[t]{2}{*}{$\mathrm{S} 2$} & S1 & S1 & S3 & Achnanthidium minutissimum (Kützing) Czarnecki \\
\hline & S2 & S2 & S4 & Amphora fogediana *Amphora eximia (Krammer) Carter \\
\hline \multirow[t]{2}{*}{ S3 } & S3 & & & Amphora lybica Ehrenberg \\
\hline & S4 & S3 & S5 & Amphora ovalis Kützing \\
\hline S4 & & & & Amphora perpusilla Grunow \\
\hline \multirow[t]{2}{*}{ S5 } & S5 & S4 & S6 & Amphora venta *Halamphora veneta (Kützing) Levkov \\
\hline & & S5 & & Bacillaria paradoxa $*$ Bacillaria paxillifera (O.F.Müller) T.Marsson \\
\hline S6 & S6 & S6 & S7 & Cocconeis placentula Ehrenberg \\
\hline S7 & S7 & S7 & S8 & Cyclotella glomerata *Lindavia glomerata (H.Bachmann) Adesalu \& Julius \\
\hline S8 & S8 & S8 & S9 & Cyclotella meneghiniana Kützing \\
\hline S9 & S9 & S9 & S10 & Cyclotella ocellata *Pantocsekiella ocellata Pantocsek \\
\hline \multirow[t]{2}{*}{ S10 } & S10 & S10 & S11 & Cyclotella operculata $*$ C. distinguenda (Kützing) Hustedt \\
\hline & & S11 & S12 & Cyclotella stelligera Cleve \& Grunow \\
\hline \multirow[t]{3}{*}{ S11 } & & S12 & S13 & Cymbella affinis Kützing \\
\hline & & S13 & & Cymbella caespitosa ${ }^{*}$ Encyonema cespitosum Kützing \\
\hline & & S14 & & Cymbella hustedtii Krasske \\
\hline S12 & & & & Cymbella lepoceros ${ }^{*}$ Cymbella neoleptoceros Krammer \\
\hline $\mathrm{S} 13$ & S11 & S15 & S14 & Cymbella microcephala $*$ Encyonopsis microcephala (Grunow) Krammer \\
\hline S14 & S12 & S16 & S15 & Cymbella silesiaca $*$ Encyonema silesiacum (Bleisch) Mann \\
\hline $\mathrm{S} 15$ & S13 & S17 & S16 & Epithemia sorex Kützing \\
\hline $\mathrm{S} 16$ & S14 & S18 & S17 & Eunotia $\mathrm{sp}$ \\
\hline $\mathrm{S} 17$ & & & S18 & Fragelaria biceps Ehrenberg \\
\hline $\mathrm{S} 18$ & S15 & S19 & S19 & Fragilaria construens (Ehrenberg) Grunow \\
\hline S19 & S16 & S20 & S20 & Fragilaria ulna (Nitzsch) Lange-Bertalot \\
\hline $\mathrm{S} 20$ & & & & Gomphonema angustatum (Kützing) Rabenhorst \\
\hline $\mathrm{S} 21$ & & & & Gomphonema gracile Ehrenberg \\
\hline $\mathrm{S} 22$ & S17 & S21 & S21 & Gomphonema minutum Agardh \\
\hline $\mathrm{S} 23$ & S18 & & S22 & Gomphonema olivaceom Hornemann \\
\hline $\mathrm{S} 24$ & S19 & $\mathbf{S 2 2}$ & $\mathbf{S 2 3}$ & Gomphonema parvulum Kützing \\
\hline $\mathrm{S} 25$ & & $\mathbf{S 2 3}$ & & Gomphonema tergestinum (Grunow) Fricke \\
\hline S26 & $\mathbf{S 2 0}$ & & & Gomphonema truncatum Ehrenberg \\
\hline $\mathrm{S} 27$ & & & & Hantzschia amphioxys (Ehrenberg) Grunow \\
\hline $\mathrm{S} 28$ & S21 & S24 & S24 & Mellosira granulata * Aulacoseira granulata (Ehrenberg) Simonsen \\
\hline \multirow[t]{2}{*}{ S29 } & $\mathbf{S 2 2}$ & S25 & S25 & Mellosira granulata var. angustissma *Aulacoseia ganulata var. angustissma (O. Muller) Simonsen \\
\hline & $\mathbf{S 2 3}$ & & S26 & Navicula accomoda $*$ Craticula accomoda (Hustedt) Mann \\
\hline \multirow[t]{2}{*}{ S30 } & S24 & S26 & S27 & Navicula anglica var. subsalsa (Grunow) Cleve \\
\hline & S25 & S27 & & Navicula digitoradiata Gregory \\
\hline \multirow[t]{2}{*}{ S31 } & & & S28 & Navicula diluviana $*$ Cymbellafalsa diluviana (Krasske) Lange-Bertalot \\
\hline & & & & Navicula gastrum * Placoneis gastrum (Ehrenberg) Mereschkovsky \\
\hline \multirow[t]{6}{*}{ S32 } & & S28 & & Navicula harderii *Sellaphora harderi (Hustedt) J.Foets \& C.E.Wetzel \\
\hline & S26 & S29 & S29 & Navicula heufleri var. leptocephala ((Brebisson) Patrick * Navicula erifuga Lange-Bertalot \\
\hline & & S30 & & Navicula incerta Grunow * Navicula salinicola Hustedt \\
\hline & S27 & & S30 & Navicula incomposita var. minor Hagelstein \\
\hline & S28 & & S31 & Navicula kriegerii *Geissleria kriegeri (Krasske) Lange-Bertalot \\
\hline & & & S32 & Navicula mutica Grunow \\
\hline \multirow[t]{2}{*}{ S33 } & S29 & S31 & & Navicula parva *Pinnularia microstauron (Ehrenberg) Cleve \\
\hline & S30 & & & Navicula phyllepta Kützing \\
\hline
\end{tabular}


Table 5 (continued)

\begin{tabular}{|c|c|c|c|c|}
\hline $\mathrm{K}$ & $\mathrm{W}$ & $\mathrm{Z}$ & M & Species name \\
\hline \multicolumn{5}{|c|}{ Species code } \\
\hline & S31 & S32 & & Navicula plathii Brockm \\
\hline & S32 & & $\mathbf{S 3 3}$ & Navicula pupula *Sellaphora pupula (Kützing) Mereschkovsky \\
\hline & & S33 & & Navicula radiosa Kützing \\
\hline $\mathrm{S} 34$ & S33 & S34 & S34 & Navicula salinarum Grunow \\
\hline $\mathrm{S} 35$ & & & & Navicula salinarum var. intermedia Grunow * Navicula capitatoradiata Germain \\
\hline \multirow[t]{2}{*}{ S36 } & S34 & S35 & S35 & Navicula viridula Kützing \\
\hline & S35 & & & Neidium bisulcatum var. baicalense (Skvortsov \& K.I.Meyer) Reimer \\
\hline \multirow[t]{2}{*}{ S37 } & S36 & S36 & & Nitzschia agnita Hustedt \\
\hline & S37 & & S36 & Nitzschia amphibia var. rostrata Hustedt \\
\hline \multirow[t]{3}{*}{$\mathrm{S} 38$} & S38 & S37 & & Nitzschia dissipata (Kützing) Rabenhorst \\
\hline & & S38 & & Nitzschia fonticola (Grunow) Grunow \\
\hline & & S39 & S37 & Nitzschia frustulum (Kützing) Grunow \\
\hline S39 & & & & Nitzschia frustulum var. bulnheimiana $*$ Nitzschia bulnheimiana (Rabenhorst) H.L.Smith \\
\hline S40 & S39 & $\mathbf{S 4 0}$ & S38 & Nitzschia liebetruthii Rabenhorst \\
\hline $\mathrm{S} 41$ & S40 & S41 & S39 & Nitzschia palea (Kützing) Smith \\
\hline S42 & S41 & & & Nitzschia paleacea Grunow in Van Heurck \\
\hline S43 & & & $\mathbf{S 4 0}$ & Nitzschia prolongata var. hoehnkii (Hustedt) Lange-Bertalot \\
\hline \multirow[t]{2}{*}{ S44 } & & & & Nitzschia umbonata Ehrenberg \\
\hline & & & S41 & Rhopalodia gibba Ehrenberg \\
\hline S45 & $\mathbf{S 4 2}$ & S42 & S42 & Synedra ulna var. ramesii $*$ Fragilaria ulna var. ramesi (Héribaud-Joseph) Hustedt \\
\hline \multirow[t]{2}{*}{ S46 } & $\mathbf{S 4 3}$ & & & Synedra tenera *Fragilaria tenera (W.Smith) Lange-Bertalot \\
\hline & & & $\mathbf{S 4 3}$ & Tabellaria binalis var. elliptica *Oxyneis binalis var. elliptica (R.J.Flower) J.C.Kingston \\
\hline
\end{tabular}

K: El-Keratten Island, W: El-Warraq Island, Z: El-Zamalek Island, M: El-Manial Island

EF values of more than 1.5 indicated that the metal's sources are mainly anthropogenic, whereas $\mathrm{EF}$ in the range of 0.5-1.5 suggested the metals come entirely from natural processes or crustal minerals (Al-Afify and Abdel-Satar 2020). Except for Cd, the studied metals in all islands shores showed minor enrichment. According to average EF values, El-Keratten, El-Warraq, and El-Zamalek shores registered severe enrichment by $\mathrm{Cd}$, while El-Manial shores have very severe enrichment, indicating anthropogenic sources for $\mathrm{Cd}$ (Fig. S2).

PLI is a valuable method for determining a sample's overall toxicity grade due to total metals content effects (Badawy et al. 2021). According to average PLI values for metals, El-Keratten shores has pollution stress during winter and summer seasons, while El-Warraq and El-Zamalek shores showed pollution level in summer season and no pollution indicated in winter. Finally, El-Manial shores did not show any pollution level during the two seasons (Table 4). The average $\mathrm{mCd}$ values found for the analyzed metals suggests nil contamination for all islands shores in the two studied periods $(\mathrm{mCd}<1.5)$ except for El-Keratten in summer seasons, it showed low pollution level $(1.5 \leq \mathrm{mCd}<2)$, Table 4 .

The average potential ecological risk (ER) for all islands shores was classified as low-grade risk $(E R<150)$, Table 4.
The average contribution of $\mathrm{Cd}$ to the ecological risk assessment was ranged from 58 to $75 \%$ in the islands shores, while the $\mathrm{Ni}$ contribution was in the range of 11-20\% (Fig. 2). El-Keratten shores had the highest accumulative capacity for $\mathrm{Ni}(20 \%)$ and $\mathrm{Cu}(11 \%)$, whereas El-Manial shores sediment recorded the highest $\mathrm{Cd}$ capacity (75\%). In general, the metallic contribution to the ecological risk trend in Nile shores follows the order; $\mathrm{Cd}>\mathrm{Ni}>\mathrm{Cu}>\mathrm{Cr}>\mathrm{Pb}>\mathrm{Mn}>\mathrm{Zn}$ $>\mathrm{Co}$ (Fig. 2). Significant Cd bio-accumulative capacity in aquatic bottom fauna, furthermore, its relative solubility in water, indicated that $\mathrm{Cd}$ potential toxicity will threaten the aquatic species in Nile islands shores (Weldegebriel et al. 2012).

TU and TRI approaches are used to assess the toxic risks in aquatic biota exposed to heavy metals contaminated sediment and consider the TEL and PEL (Gao et al. 2018; Zhang et al. 2016). If the sediment $\Sigma T U$ for metals was minimal $(<4)$, no significant harmful effect on aquatic organisms is registered (Gao et al. 2018). The summer season samples recorded higher average $\Sigma \mathrm{TU}$ for all Nile shores compared with winter season, where El-Keratten, El-Warraq and ElZamalek shores recorded high $\Sigma T U(>4)$ with significant harmful effect on aquatic biota, Table 4 . Figure 2 showed the average contributions of each metal to the $\sum \mathrm{TU}$ and 


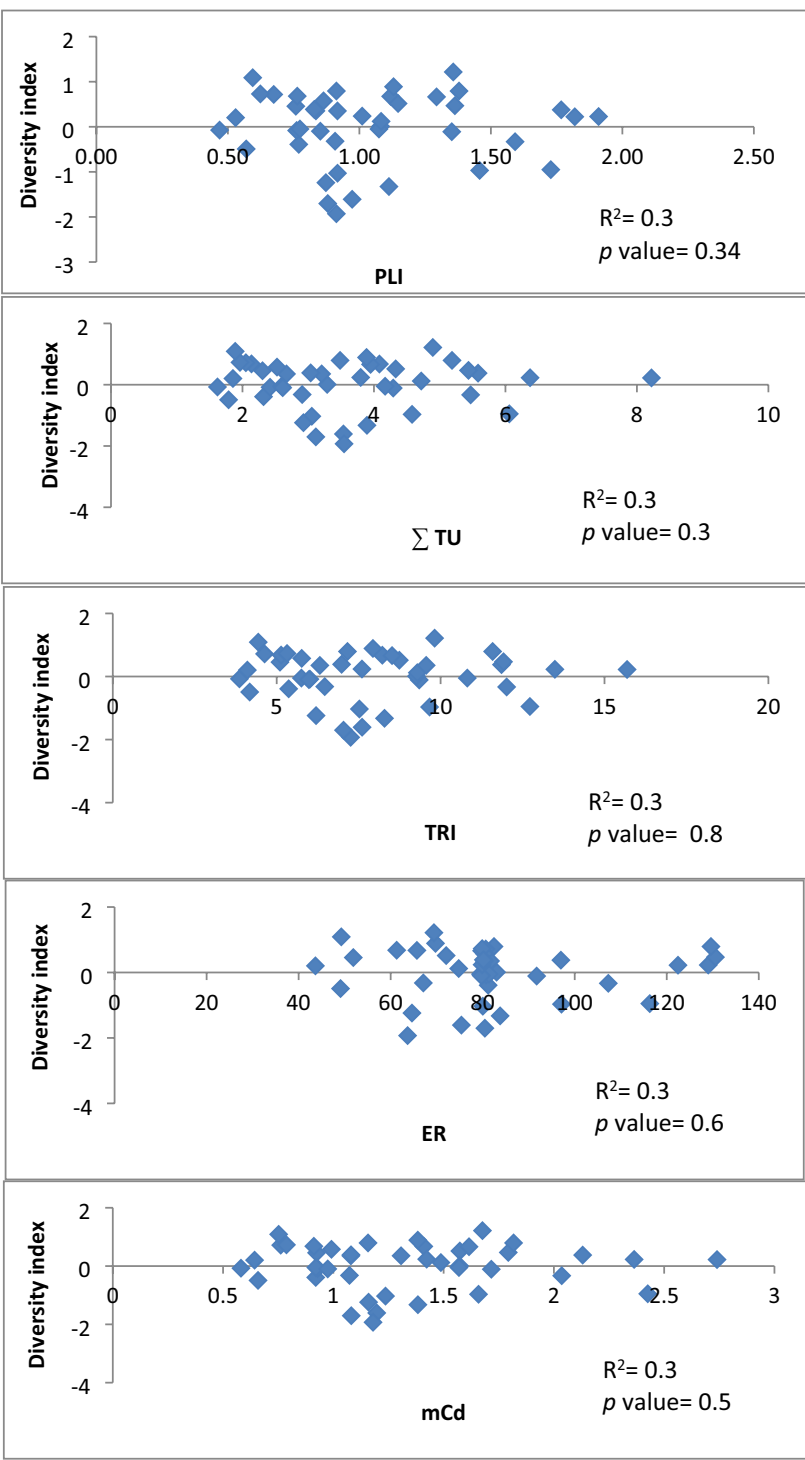

Fig. 6 Nonparametric multiplicative regression exhibiting the relationship between the diversity diatom index and metal indices at all studying sites of the four islands

declared that $\mathrm{Ni}, \mathrm{Cr}$ and $\mathrm{Cd}$ accounted for the majority of the overall toxicity of the shores sediment. According to the average TRI, moderate toxic risk from metals was observed for El-Keratten shores in summer season, where their values were more than 10, while El-Warraq, El-Zamalek, and ElManial shores sediments were at low toxic risk in the two studied periods, Table 4 .

\subsection{Attached diatoms community}

A total of 112 diatom species (including species and varieties) belonging to 24 genera were identified in the total samples set, most of the diatoms encountered in the study were cosmopolitan. The most diverse genera were Navicula
(25 species) and Nitzschia (20 species). Achnantheaceae and Fragilariaceae were the most frequent pinnate genera, while Cyclotella and Mellosira were the most frequent centric genera.

According to diversity Shannon index, the recommended season for sampling diatoms was summer, as winter samples possessed many taxa with less dominance. In general, the species diversity was higher in summer at most sites than in winter samples (Fig. 3). During the winter and summer, site $\mathrm{Z} 1$ had the lowest diversity value of 1.75 and 1.08 , respectively, while the maximum diversity was recorded at site W1 in the winter with a value of 3.92 and W2 in the summer with a value of 4.79 . The high levels of diversity at some sites, such as K6 and Z6, were linked to high levels of sedimentation.

The evenness values in winter were in the range of 0.33-0.66, where the lowest value was recorded at site Z5 and reflected the high dominance of Cyclotella ocellata which represented $73 \%$ of total species abundance and was associated with a high Cd level (Fig. 4). In summer, the values ranged between 0.48 and 0.69 , where the minimum value was observed at site M2 and reflected the high dominance distribution between Cyclotella ocellata and Fragilaria construens which represented $41 \%$ and $42 \%$ of total abundance, respectively, and was associated with a high percentage of sand sediment texture $99.6 \%$.

Diatom assemblages (expressed as the relative abundance of species that had minimum relative abundances $\geq$ of $1 \%$ so, rare species were not included in the analysis) were correlated with sediment texture, carbonate, $\mathrm{OM}$ and metal levels. The CCA applied on samples of El-Keratten Island revealed that sediment variables represented $47.6 \%$ of the variance in the weighted averages of diatom assemblage. As a result, Fig. 5 depicted the observed distribution based on sediment variables. Amphora lybica, Fragilaria ulna, Gomphonema angustatum, Mellosira granulata var. angustissma and Navicula viridula was close to $\mathrm{Ni}$ and Co points and so on. The full name of species abbreviation in Fig. 5 was listed in Table 5. Most species were sensitive to high metal levels, where metal as $\mathrm{Mn}$ and $\mathrm{Pb}$ in addition to $\mathrm{OM}$ and gravel texture negatively correlated to species axis 1 with weighted correlation matrix of $-0.2,-0.4,-0.7$, and -0.6 , respectively. For El-Warraq Island samples the sediment variables represented $47.8 \%$ of the variance in the weighted averages of diatom assemblage. The most impactful variable, $\mathrm{Al}$, had a weighted correlation matrix of 0.70 with species axis 1 , followed by $\mathrm{OM}$ and $\mathrm{Pb}$, which had weighted correlation matrix of -0.64 and -0.57 , respectively (Fig. 5). In El-Zamalek Island, the sediment variables represented $52.8 \%$ of the variance in the weighted averages of the diatom community. Most variables demonstrated high correlations with species axis 1 , such as $\mathrm{Mn}, \mathrm{Ni}, \mathrm{Co}$, and $\mathrm{Cd}$ with a weighted correlations matrix of $-0.5,-0.55,-0.6$, and 0.45 , respectively. 
Table 6 Presence and absence of the recorded benthic invertebrates in the studied sites of Nile shores

\begin{tabular}{|c|c|c|c|c|c|c|c|c|c|}
\hline Taxa & El-Kerateen & El-Warrak & El-Zamalek & El-Manial & Taxa & El-Kerateen & El-Warrak & El-Zamalek & El-Manial \\
\hline \multicolumn{10}{|l|}{ Mollusca: } \\
\hline $\begin{array}{l}\text { Melanoides tuber- } \\
\text { culata }\end{array}$ & $6+$ & $6+$ & $6+$ & $5+$ & Arthropoda: & & & & \\
\hline Valvata nilotica & $5+$ & $5+$ & $1+$ & $1+$ & $\begin{array}{l}\text { Chlamidothica } \\
\text { unispinosa }\end{array}$ & $3+$ & $1+$ & - & - \\
\hline $\begin{array}{l}\text { Cleopatra bulmo- } \\
\text { ides }\end{array}$ & $5+$ & $4+$ & $4+$ & $5+$ & $\begin{array}{l}\text { Chironomidae } \\
\text { pupae }\end{array}$ & - & $5+$ & $1+$ & $3+$ \\
\hline Bulinus truncatus & $4+$ & $2+$ & $1+$ & - & $\begin{array}{l}\text { Chironomidae } \\
\text { larvae }\end{array}$ & $5+$ & $6+$ & $6+$ & $6+$ \\
\hline Bellyma unicolor & $2+$ & $1+$ & $2+$ & $2+$ & Cainus sp & $2+$ & $1+$ & $2+$ & $3+$ \\
\hline $\begin{array}{l}\text { Gyraulus ehren- } \\
\text { bergi }\end{array}$ & $4+$ & - & - & - & Ostracoda & $1+$ & $1+$ & - & - \\
\hline Pirenella conica & $4+$ & $6+$ & $5+$ & $4+$ & Cardina nilotica & $2+$ & - & - & - \\
\hline Ferrissia sp. & $2+$ & $1+$ & - & - & Libellula sp. & $1+$ & - & - & - \\
\hline Pisidium pirothi & - & - & $1+$ & $1+$ & Ischnura sp & $1+$ & - & - & - \\
\hline Lymnaea sp & $4+$ & - & - & - & Trichoptera larvae & $1+$ & - & $1+$ & $2+$ \\
\hline $\begin{array}{l}\text { Theodoxus niloti- } \\
\text { cus }\end{array}$ & $3+$ & $4+$ & $4+$ & $4+$ & & & & & \\
\hline Lanistes carinatus & $3+$ & - & - & - & Annelida: & & & & \\
\hline Helisoma duryi & & $4+$ & - & - & $\begin{array}{l}\text { Limnodrilus ude- } \\
\text { kemianus }\end{array}$ & $6+$ & $5+$ & $5+$ & $4+$ \\
\hline $\begin{array}{l}\text { Gabbiella sen- } \\
\text { aariensis }\end{array}$ & $5+$ & $5+$ & $3+$ & $3+$ & $\begin{array}{l}\text { Limnodrilus } \\
\quad \text { hoffmeisteri }\end{array}$ & $6+$ & $5+$ & $4+$ & $5+$ \\
\hline Spharium simile & $2+$ & $4+$ & $4+$ & $1+$ & $\begin{array}{l}\text { Branchiura sow- } \\
\text { erbyi }\end{array}$ & $1+$ & - & $1+$ & - \\
\hline $\begin{array}{l}\text { Corbicula flumi- } \\
\text { nalis }\end{array}$ & $6+$ & $5+$ & $6+$ & $6+$ & Pristina sp. & $1+$ & $2+$ & $3+$ & $1+$ \\
\hline $\begin{array}{l}\text { Cealatura } \\
\text { prasidense }\end{array}$ & $2+$ & $1+$ & $3+$ & $2+$ & Helobdella conifer & $3+$ & $2+$ & $2+$ & $2+$ \\
\hline $\begin{array}{l}\text { Cealatura teretius- } \\
\text { cula }\end{array}$ & - & $1+$ & $1+$ & $3+$ & Barbronia sp & $2+$ & - & - & - \\
\hline Mutela sp & - & - & $1+$ & - & & & & & \\
\hline
\end{tabular}

+ : present; -: absent; number beside + : number of sites

Samples of sites 1, 2, and 5 at El-Manial Island were did not collected in the summer season

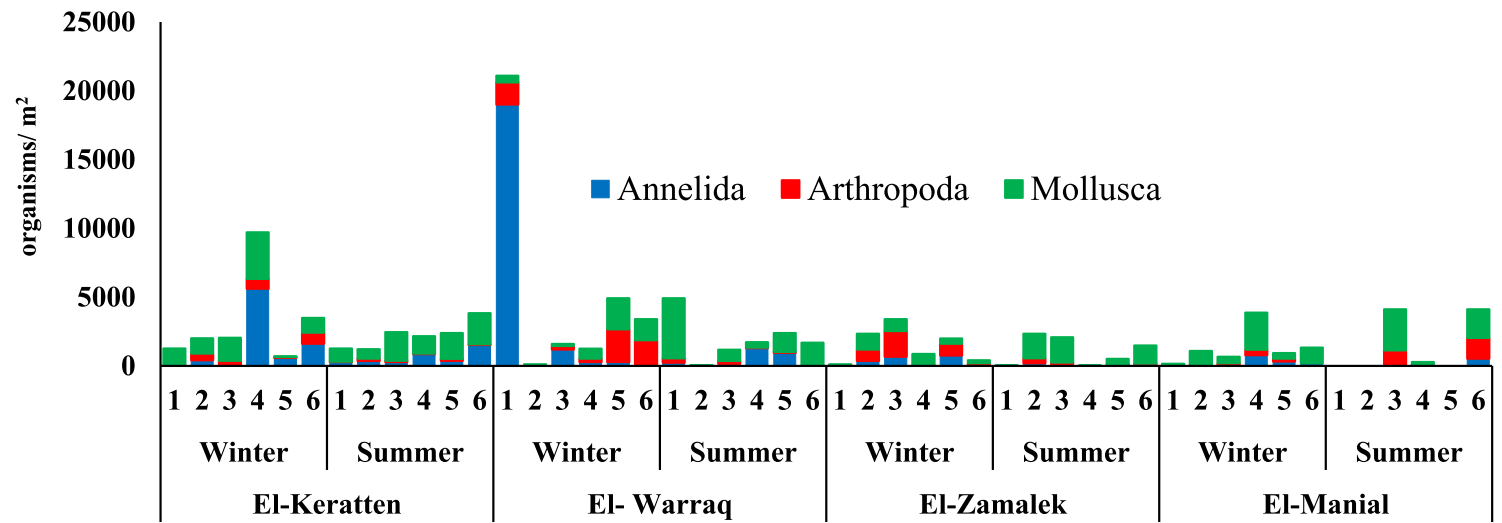

Fig. 7 Average population density of macrobenthic invertebrates at the studied islands. Note: M1, M2, and M5 not collected during summer 
Table 7 Distribution of total number of organisms (organisms $/ \mathrm{m}^{2}$ ) and the most dominant taxa of macrobenthic invertebrates (MBI), and the percentage of the dominant taxa to their phylum

\begin{tabular}{|c|c|c|c|c|c|c|c|c|c|c|}
\hline \multirow[t]{2}{*}{ Island } & \multirow[t]{2}{*}{ Season } & \multicolumn{2}{|c|}{ Annelida } & \multicolumn{2}{|c|}{ Arthropoda } & \multicolumn{4}{|c|}{ Mollusca } & \multirow{2}{*}{$\begin{array}{l}\text { Total } \\
\text { MBI }\end{array}$} \\
\hline & & $\begin{array}{l}\text { Total } \\
\text { Ann }\end{array}$ & $\begin{array}{l}\% \\
\mathrm{Lim}\end{array}$ & $\begin{array}{l}\text { Total } \\
\text { Arth }\end{array}$ & $\begin{array}{l}\% \\
\text { Chi. } 1\end{array}$ & $\begin{array}{l}\text { Total } \\
\text { Mol }\end{array}$ & $\begin{array}{l}\% \\
\text { Cor }\end{array}$ & $\begin{array}{l}\% \\
\mathrm{Cle}\end{array}$ & $\begin{array}{l}\% \\
\text { Mel }\end{array}$ & \\
\hline \multirow[t]{4}{*}{ El-Keratten } & Winter & 1387 & 85.15 & 390 & 77.18 & 1431 & 12.86 & 11.74 & 15.02 & 3208 \\
\hline & Summer & 614 & 68.08 & 86 & 44.19 & 1524 & 12.86 & 5.38 & 22.64 & 2224 \\
\hline & Average & 1001 & 76.61 & 238 & 60.68 & 1478 & 12.86 & 8.56 & 18.83 & 2716 \\
\hline & $\%$ to $\mathrm{MBI}$ & 36.86 & & 12.16 & & 54.42 & & & & \\
\hline \multirow[t]{4}{*}{ El-Warraq } & Winter & 3483 & 27.22 & 1039 & 46.29 & 874 & 64.53 & 3.32 & 6.86 & 5396 \\
\hline & Summer & 440 & 97.95 & 108 & 85.19 & 1447 & 24.95 & 2.83 & 41.60 & 1995 \\
\hline & Average & 1962 & 62.59 & 574 & 65.74 & 1161 & 44.74 & 3.08 & 24.23 & 3696 \\
\hline & $\%$ to $\mathrm{MBI}$ & 53.08 & & 8.76 & & 31.41 & & & & \\
\hline \multirow[t]{4}{*}{ El-Zamalek } & Winter & 323 & 87.31 & 618 & 97.41 & 583 & 61.41 & 0.00 & 22.30 & 1524 \\
\hline & Summer & 82 & 85.37 & 105 & 63.81 & 896 & 25.11 & 2.79 & 23.66 & 1083 \\
\hline & Average & 203 & 86.34 & 362 & 80.61 & 740 & 43.26 & 1.40 & 22.98 & 1304 \\
\hline & $\%$ to $\mathrm{MBI}$ & 15.57 & & 27.76 & & 56.75 & & & & \\
\hline \multirow[t]{4}{*}{ El-Manial } & Winter & 238 & 97.06 & 139 & 93.53 & 963 & 32.61 & 6.96 & 25.03 & 1340 \\
\hline & Summer & 196 & 58.16 & 893 & 67.41 & 1754 & 4.68 & 26.74 & 24.91 & 2843 \\
\hline & Average & 217 & 77.61 & 516 & 80.47 & 1359 & 18.64 & 16.85 & 24.97 & 2092 \\
\hline & $\%$ to $\mathrm{MBI}$ & 10.37 & 75.79 & 24.67 & 71.88 & 64.96 & 29.88 & 7.47 & 22.75 & \\
\hline
\end{tabular}

Lim, Limnodrilus spp.; Chi., 1.. Chironomid larvae; Cor., Corbicula sp.; Cle., Cleopatra bulmoides; Mel., Melanoides tuberculata
According to sediment texture variables, species Cocconeis placentula, Navicula plathii, and Nitzschia dissipata were associated with gravel, while Cyclotella operculata, Gomphonema parvulum and Nitzschia frustulum were associated with sand and finally Achnanthes minutissma was associated with mud (Fig. 5). All variables (excluding Zn, gravel, and sand) were negatively correlated with species axis 1 at El-Manial shores sediment (Fig. 5). Despite the fact that the weighted correlation matrix for all variables was low, these variables accounted for $68.4 \%$ of the variance in the weighted averages of diatom assemblage as calculated from obtained eigenvalues, as a cumulative effect of variables. Achnanthes minutissma, Navicula diluviana, Nitzschia amphibia var. rostrata, and Rhopalodia gibba were closed to Zn, whereas Amphora ovalis, Amphora venta, and Epithemia sorex were closed to the carbonate point. Despite metal concentrations exceeding international guidelines, numerous species of diatoms were recorded, demonstrating that diatoms may adapt to and survive in heavy metal-contaminated habitats (Ubando et al. 2021; Walha et al. 2021) by biosorption or bioaccumulation of metals (Pistocchi et al. 2019).

In all sampling sites, the nonparametric multiplicative regression (NPMR) was used to fit and compare several heavy metal indices (mCd, ER, TRI, $\Sigma T U$, and PLI) to the diatom community diversity index. Non-significant associations were found in the NPMR regression of diatom diversity index with heavy metal indices scores $\left(R^{2}=0.3, P\right.$ value $=0.5,0.6,0.8,0.3$, and 0.3 for $\mathrm{mCd}, \mathrm{ER}, \mathrm{TRI}, \Sigma \mathrm{TU}$, and PLI, respectively) (Fig. 6). This lack of significance with diatom diversity could be explained by the fact that most species are more sensitive to some stressors (such as sediment texture) than metals, where diversity was substantially connected with sand and mud sediment $(r=-0.5$ and 0.5 , respectively, with $P$ value 0.05 ). Metal pollution had little influence on diatom diversity at the research sites, but the changes in assemblage composition, distribution, and species dominance were influenced markedly by heavy metals (Hirst et al. 2002), particularly at the dominance level by a slight shift of subdominant from centric diatom genera to more tolerant species, such as Fragilaria construens. Therefore, the examining of diatom status is considered a successful tool for biomonitoring of metals contaminated habitat because of its preference and tolerance to diverse sediment factors (Malinowska-Gniewosz et al. 2018).

\subsection{Macrobenthic invertebrates (MBI)}

Thirty-four species of benthic invertebrates were identified in the collected samples from the investigated islands shores during winter and summer; of these 9 arthropods, 6 annelids, and 19 molluscs, Table 6. Mollusca were the dominant group by three taxa (Corbicula sp., Cleopatra bulmoides, and Melanoides tuberculata) at all studied islands, except for El-Warraq Island; Annelida was the dominant group (Fig. 7). The highest number of species (17 species) was observed at El-Keratten and El-Manial islands followed by El-Warraq and El-Zamalek islands which registered 14 species for 

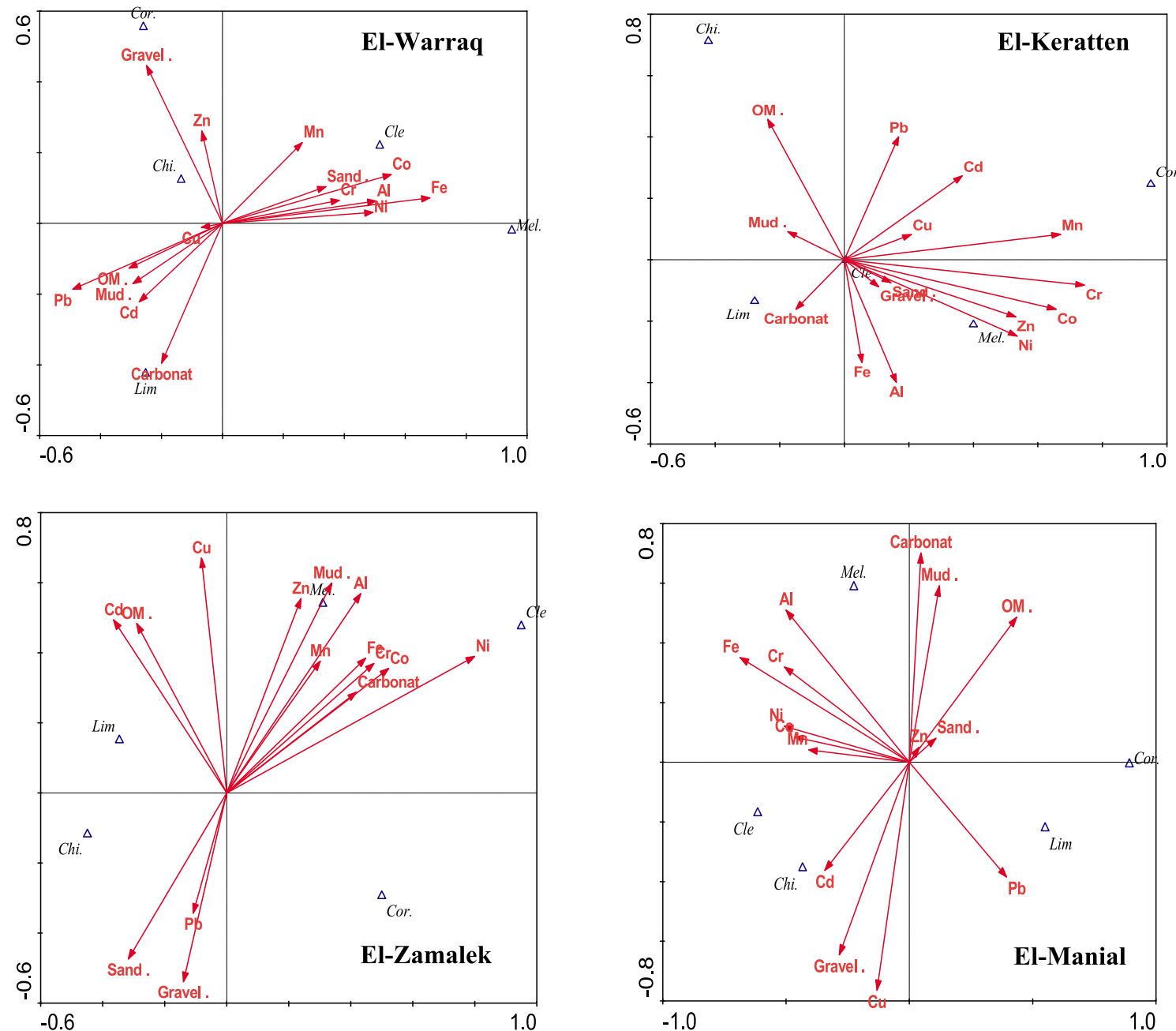

Fig. 8 Ordination diagram showing the result of CCA analysis for MBI in the four studied islands (Lim, Limnodrilus spp.; Chi.1.. Chironomid larvae; Cor., Corbicula sp.; Cle., Cleopatra bulmoides; and Mel., Melanoides tuberculata)

each. The annelid Limnodrilus spp. were the most dominant annelid genera in the four islands $(75.79 \%$ to total annelid count), they were recorded in most of the studied sites. Saad et al. (2015), Abdel-Gawad and Mola (2014) and Mola and Abdel-Gawad (2014) mentioned Annelida was the dominant group of total macrobenthos in Nasser Lake and its khors. El-Warraq Island inhabited the richest number of MBI compared with other islands especially during the winter season, Table 7. The arthropod assemblage was composed mainly of chironomids ( $71.88 \%$ to total arthropods count) that could be related to sediment conditions. The dominance of chironomids indicates their broad range habitat preference and their ability to adapt to seasonal changes. The abundance of macroinvertebrates taxa during the winter and summer seasons have been linked to their diverse habitat preferences and capacity to adjust to seasonal changes (Oppong et al. 2021). CCA was carried out to verify the impact of metals and sediment variables on the most dominant macroinvertebrate taxa (five taxa) for the studied islands (Fig. 8). The recorded taxa appeared different actions from island to other according to their substrate texture of sediment, metals concentration, $\mathrm{OM}$, and carbonate percent.

El-Keratten Island was the second richest island in bottom fauna, especially during winter, Table 7 . K4 occupied the highest PD due to the high number of annelida and mollusca, while the poorest site was K5. CCA analysis indicated that organic matter, carbonate, and $\mathrm{Zn}$ were the most effective factors on MBI. The CCA biplot diagram has shown that Limnodrilus was closed to carbonate, while the chironomus larvae was close to organic matter. Melanoids were correlated positively with $\mathrm{Ni}, \mathrm{Zn}, \mathrm{Co}$, and $\mathrm{Cr}$, while it correlated negatively with organic matter and mud (Fig. 8). El-Warraq Island had a population density of 5396 and 2011 organisms $/ \mathrm{m}^{2}$ during winter and summer, respectively. W1 occupied the highest PD during the two seasons due to the richness of Annelida during winter and Mollusca during 
summer. Arthropoda reached its maximum number in W5, W6, and W1. Arthropoda had weak representation, especially during summer, as recorded by Abdel Gawad et al. (2014) and Abdel Gawad and Mola (2014). CCA indicated that, the most important mineral affecting the distribution of $\mathrm{MBI}$ at El-Warraq Island were $\mathrm{Cr}, \mathrm{Al}, \mathrm{Ni}, \mathrm{Co}$, and $\mathrm{Mn}$ in addition to soil texture and carbonate. The CCA biplot diagram has shown that Limnodrilus has a positive correlation with carbonate, Cleoptra was positively correlated with sand, and finally Corbicula was positively correlated with gravel texture (Fig. 8). In El-Zamalek Island, the average population density was 1524 and 1083 organisms $/ \mathrm{m}^{2}$ in winter and summer, respectively (Table 7). The highest $\mathrm{PD}$ was recorded at $\mathrm{Z} 3$ due to the increase in Arthropoda and Mollusca number, while the poorest site was Z1 (114 organisms $/ \mathrm{m}^{2}$ ). The CCA biplot diagram had shown that the Corbicula correlated negatively with $\mathrm{Cu}, \mathrm{Cd}$, and $\mathrm{OM}$, while Melanoides correlated positively with $\mathrm{Zn}, \mathrm{Al}$, and mud (Fig. 8). El-Manial Island was the poorest island in bottom fauna during winter, where the average population density was reached 1340 organisms $/ \mathrm{m}^{2}$, Table 6 . M4 encountered the highest PD with the high number of Mollusca, while the lowest was observed in M1. CCA revealed the most correlated variables positively with species axis 1 were $\mathrm{Al}, \mathrm{Fe}$, Mn, and sand (Fig. 8).

\section{Conclusion}

The present study attained its primary goal by reporting the baseline data on heavy metal distribution and assessment on the shores of four Nile islands in Great Cairo. In addition, the impact of sediment variables on the distribution of benthic diatoms and macroinvertebrates on islands shores was investigated. According to sediment quality guidelines, $\mathrm{Ni}$ and $\mathrm{Cd}$ had their accumulation more than TEL; hence they were occasionally associated with adverse biological effects. While $\mathrm{Zn}, \mathrm{Cu}$, and $\mathrm{Cr}$ levels surpassed the TEL in some sampling sites along different islands shores. The agricultural and domestic wastes can be a significant source of metals inputs into the Nile shores. According to average PLI values for metals, El-Keratten shores have pollution stress during the winter and summer seasons, while El-Warraq and El-Zamalek shores showed pollution levels in the summer season and no pollution was indicated in the winter. Finally, El-Manial shores did not show any pollution level during the two seasons. Metal pollution had little effect on diatom diversity at the Nile shores; however, metals had a significant impact on diatom assemblage composition, distribution, and species dominance. Some diatom taxa showed high adaption and tolerance with high levels of metals, as well as significant uniform relationships were recorded with sediment texture, mostly sand, and mud. Therefore, evaluating diatom status is regarded as a successful approach for biomonitoring of metals contaminated habitats. Different sediment characteristics affected the dominating taxa and groups of macrobenthic invertebrates on different islands sediment, with the levels and types of such variables varying from one species to another.

Supplementary Information The online version contains supplementary material available at https://doi.org/10.1007/s12210-022-01051-2.

Funding Open access funding provided by The Science, Technology \& Innovation Funding Authority (STDF) in cooperation with The Egyptian Knowledge Bank (EKB). The National Institute of Oceanography and Fisheries supported this research as part of a larger mission to investigate the environmental conditions of Nile River islands shores.

Availability of data and materials The data can be available on request.

\section{Declarations}

Conflict of interest The authors declare that there are no conflicts of interest.

Open Access This article is licensed under a Creative Commons Attribution 4.0 International License, which permits use, sharing, adaptation, distribution and reproduction in any medium or format, as long as you give appropriate credit to the original author(s) and the source, provide a link to the Creative Commons licence, and indicate if changes were made. The images or other third party material in this article are included in the article's Creative Commons licence, unless indicated otherwise in a credit line to the material. If material is not included in the article's Creative Commons licence and your intended use is not permitted by statutory regulation or exceeds the permitted use, you will need to obtain permission directly from the copyright holder. To view a copy of this licence, visit http://creativecommons.org/licenses/by/4.0/.

\section{References}

Abdel Gawad SS, Mola HRA, Fishar MR (2014) Macrobenthos in Lake Nasser, In: El-Shabrawy GM (ed) Ecological Basis for Lake Nasser Ecosystem, Lap Lambert Academic Publishing, pp 213-231

Abdel Gawad SS, Mola HRA (2014) Macrobenthic invertebrates in the main channel of Lake Nasser, Egypt. Egypt J Aquat Res 40:405-414

Abdel-Satar AM (2005) Quality of River Nile sediment from Idfo to Cairo. Egypt J Aquat Res 31:182-199

Abdel-Satar AM, Ali MHH, Goher ME (2017a) Indices of water quality and metal pollution of Nile River. Egypt Egypt J Aquat Res 43:21-29

Abdel-Satar AM, Ali MHH, Goher ME (2017b) Distribution and speciation of $\mathrm{Fe}, \mathrm{Mn}, \mathrm{Zn}, \mathrm{Cu}, \mathrm{Pb}$ and $\mathrm{P}$ in surface sediments of Mariut Lake, Egypt. Oceanol Hydrobiol Stud 46:154-167

Abou El-Anwar E, Salman S, Asmoay A, Elnazer A (2021) Geochemical, mineralogical and pollution assessment of River Nile sediments at Assiut Governorate, Egypt. J Afr Earth Sci 180:104227

Abrahim GMS, Parker RJ (2008) Assessment of heavy metal enrichment factors and the degree of contamination in marine sediments from Tamaki Estuary, Auckland. N Z Estuar Coast Shelf Sci 136:227-238 
Al-Afify ADG, Abdel-Satar AM (2020) Risk assessment of heavy metal pollution in water, sediment and plants in the Nile River in the Cairo region. Egypt Oceanol Hydrobiol Stud 49:1-12

ANS (The Academy of Natural Sciences) (2002) Protocols for the analysis of algal samples collected as part of the U.S. Geological Survey National Water-Quality Assessment Program, 02-06

Badawy WM, Duliu OG, El Samman H, El-Taher A, Frontasyeva MV (2021) A review of major and trace elements in Nile River and Western Red Sea sediments: An approach of geochemistry, pollution, and associated hazards. Appl Radiat Isotopes 170:109595

Brinkhurst RO (1966) A contribution towards a revision of the aquatic Oligochaeta of Africa. Zool Afr 2:131-166

Brinkhurst RO, Jamison BGM (1971) Aquatic Oligochaeta of the World. University of Toronto Press, Ontario

Brown DS, Fison T, Southgate VR, Wright CA (1984) Aquatic snails of Jonglei region, southern Sudan and transmission of trematode parasites. Hydrobiology 110:247-271

Clarke KR, Gorley RN (2001) PRIMER v5: User manual, PRIMERE, Plymouth UK

EPA (Environmental Protection Agency) (2006) Region III BTAG Freshwater Sediment Screening Benchmarks 8/2006

Folk RL (1974) Petrology of sedimentary rocks. Hemphills, Austin, TX

Gao L, Wang Z, Li S, Chen J (2018) Bioavailability and toxicity of trace metals ( $\mathrm{Cd}, \mathrm{Cr}, \mathrm{Cu}, \mathrm{Ni}$, and $\mathrm{Zn}$ ) in sediment cores from the Shima River, South China. Chemosphere 192:31-42

Goldman C (2009) Micronutrient elements (Co, Mo, Mn, Zn, Cu), In: Likens GE (ed) Biogeochemistry of Inland Waters, CA: Academic Press, San Diego, pp 378-382

Hakanson L (1980) An ecological risk index for aquatic pollution control. A Sedimentological Approach. Water Res 14:975-1001

Hakanson L (1988) Metal monitoring in coastal environments. In: Lacerda LD, Patchineelam SR (eds) Seeliger U. Metals in Coastal Environments of Latin America, Springer Verlag, pp 240-257

Hirst H, Juttner I, Ormerod SJ (2002) Comparing the responses of diatoms and macroinvertebrates to metals in upland streams of Wales and Cornwall. Freshw Biol 47:1752-1765

Hussein AM, Mahmoud RK, Sillanpää M, Abdel Wahed MSM (2021) Impacts alum DWTPs sludge discharge and changes in flow regime of the Nile River on the quality of surface water and cultivated soils in Fayoum watershed, Egypt. Sci Total Environ 766: 144333

Kouadia L, Trefry JH (1987) Saline trace metal contamination in the Ivory. Air Water Soil Pollut 32:145-154

Lavoie I, Hamilton PB, Morin S, Tiam SK, Kahlert M, Gonçalves S et al (2017) Diatom teratologies as biomarkers of contamination: are all deformities ecologically meaningful? Ecol Ind 82:539-550

Long S, Hamilton PB, Dumont HJ, Rong L, Wu Z, Chen C, Guo Y, Tang J, Fan J, Li C, Zhang T (2019) Effect of algal and bacterial diet on metal bioaccumulation in zooplankton from the Pearl River, South China. Sci Total Environ 675:151-164

Loring DH, Rantala RTT (1992) Manual for the geochemical analyses of marine sediments and suspended particulate matter. Mar EarthSci Rev 32:235. https://doi.org/10.1016/0012-8252(92)90001-A

MacDonald DD, Ingersoll CG, Berger TA (2000) Development and evaluation of consensus-based sediment quality guidelines for freshwater ecosystems. Arch Environ Contam Toxicol 39:20-31

Maina CW, Sang JK, Raude JM, Mutua BM (2019) Geochronological and spatial distribution of heavy metal contamination in sediment from Lake Naivasha, Kenya. J Radiat Res Appl Sci 12:37-54

Malinowska-Gniewosz A, Czerwik-Marcinkowska J, Massalski A, Kubala-Kukuś A, Majewska U, Jankowski M (2018) Relationships between diatoms and environmental variables in industrial water biotopes of Trzuskawica S.A. (Poland). Open Chem 16:272-282
American Society of Agronomy (1982) Methods of Soil analysis. Part 2 Chemical and microbiological properties. Madison, Wisconsin, USA

Mola HRA, Abdel-Gawad SS (2014) Spatio-temporal variations of macrobenthic fauna in Lake Nasser khors, Egypt. Egypt J Aquat Res 40:415-423

Müller G (1969) Index of geo-accumulation in sediments of the Rhine River. Geol J 2:109-118

Mulrooney SB, Hausinger RP (2003) Nickel uptake and utilization by microorganisms. FEMS Microbiol Rev 27:239-261

Nazeer S, Hashmi MZ, Malik RN (2016) Distribution, risk assessment, and source identification of heavy metals in surface sediments of River Soan. Pakistan CSAWAC 44(9):1085-1260

Oppong SK, Nsor CA, Buabeng GK (2021) Response of benthic invertebrate assemblages to seasonal and habitat condition in the Wewe River, Ashanti region (Ghana). Open Life Sci 16:336-353

Othman AA, Al-Afify ADG, Abdel-Satar AM, Ramadan MF (2021) Quality assessment of surface water using the Nile Chemical Pollution Index (NCPI) and microbiological pollution of the Rosetta Branch (Nile River, Egypt). Afr J Aquat Sci 46(2):129-141

Pandey LK, Bergey EA, Jie L, Park J, Choi S, Lee H, Depuydt S, Han $\mathrm{T}$ (2017) The use of diatoms in ecotoxicology and bioassessment: insights, advances and challenges. Water Res 118:39-58

Pedersen F, Bjørnestad E, Andersen HV, Kjølholt J, Poll C (1998) Characterization of sediments from Copenhagen Harbour by use of biotests. Water Sci Technol 37:233-240

Pennak RW (1953) Fresh Water Invertebrates of the United States. University of Colorado-The Ronald Press Company, New York

Pistocchi R, Dao LTH, Mikulic P, Beardall J (2019) Metal pollution in water: toxicity, tolerance and use of algae as a potential remediation solution. Springer, Cham, pp 471-500

Qu X, Wu N, Tang T, Cai Q, Pak Y-S (2010) Effects of heavy metals on benthic macroinvertebrate communities in high mountain streams. Int J Lim 46:291-302

Qu C, Chena W, Hu X et al (2019) Heavy metal behaviour at mineralorgano interfaces: Mechanisms, modelling and influence factors. Environ Int 131: 104995

Raslan Y, Salama R (2015) Development of Nile River islands between Old Aswan Dam and new Esna barrages. Water Sci 29:77-92

Rzętała MA (2016) Cadmium contamination of sediments in the water reservoirs in Silesian Upland (southern Poland). J Soils Sediments 16:2458-2470

Saad AA, Emam WM, Mola HRA, Omar HM (2015) Effect of pollution on macrobenthic invertebrates in some localities along the River Nile at Great Cairo, Egypt. Egypt J Aquat Biol Fish 19(2):1-11

Sadek N (2013) Island development impacts on the Nile River morphology. Ain Shams Eng J 4:25-41

Sayed MF, Abdel-Satar AM (2009) Chemical assessment of Wadi ElRayan Lakes - Egypt. American-Eurasian J Agric Environ Sci 5:53-62

Shalaby SEM, El-Saadany SS, Abo-Eyta AM, Abdel-Satar AM, AlAfify ADG, Abd El-Gleel WMM (2018) Levels of pesticide residues in water, sediment, and fish samples collected from Nile River in Cairo. Egypt Environ Forensic 19:228-238

Taha LGE (2014) Assessment of urbanization encroachment over Al-Monib island using fuzzy post classification comparison and urbanization metrics. Egypt J Remote Sens Space Sci 17:135-147

Tang W, Sun L, Shu L, Wang C (2020) Evaluating heavy metal contamination of riverine sediment cores in different land-use areas. Front Environ Sci Eng 14(6):104

ter Braak CJF (1987) Calibration. In: ter Braak CJF, van Tongeren OFR (eds) Jongman RHG. Data analysis in community and landscape ecology, Pudoc Wageningen, pp 78-90 
Tomlinson DC, Wilson JG, Harris CR, Jeffrey DW (1980) Problems in the assessment of heavy metals levels in estuaries and the formation of pollution index. Helgoland Mar Res 33:566-575

Ubando AT, Africa ADM, Maniquiz-Redillas MC, Culaba AB, Chen W-H, Chang J-S (2021) Microalgal biosorption of heavy metals: a comprehensive bibliometric review. J Hazard Mater 402:123431

Unda-Calvo J, Ruiz-Romera E, Martínez-Santos M, Vidal M, Antigüedad I (2020) Multivariate statistical analyses for water and sediment quality index development: a study of susceptibility in an urban river. Sci Total Environ 711:135026

Walha LD, Hamzaa A, Keskes FA, Cibic T, Mechid A, Mahfoudia M, Sammaria C (2021) Heavy metals accumulation in environmental matrices and their influence on potentially harmful dinoflagellates development in the Gulf of Gabes (Tunisia). Estuar Coast Shelf Sci 254:107317

Weldegebriel Y, Chandravanshi BS, Wondimu T (2012) Concentration levels of metals in vegetables grown in soils irrigated with river water in Addis Ababa, Ethiopia. Ecotoxicol Environ Saf 77:57-63

Wirth WW, Stone A (1963) Aquatic diptera, In: Usinger RL (ed) Aquatic of California, Univ. Calif., P.R. Los Angeles, pp 372-482
Yacoub AM, Abd MSA, el-Satar AM, (2021) Accumulation of heavy metals in tilapia fish species and related histopathological changes in muscles, gills and liver of Oreochromis niloticus occurring in the area of Qahr El-Bahr, Lake Al-Manzalah. Egypt Oceanol Hydrobiol Stud 50(1):1-15

Yahaya MI, Jacob AG, Agbendeh ZM, Akpan GP, Kwasara AA (2012) Seasonal potential toxic metals contents of Yauri river bottom sediments: North western Nigeria. J Environ Chem Ecotoxicol $4: 212-221$

Zhang G, Bai J, Zhao Q, Lu Q, Jia J, Wen X (2016) Heavy metals in wetland soils along a wetland-forming chronosequence in the Yellow River Delta of China: Levels, sources and toxic risks. Ecol Ind 69:331-339

Publisher's Note Springer Nature remains neutral with regard to jurisdictional claims in published maps and institutional affiliations. 